\title{
MASTER
}

\section{A Model for the Movement and Distribution of Fish in a Body of Water}

D. L. DeAngelis

ENVIRONMENTAL SCIENCES DIVISION

Publication No. 1173

OAK RIDGE NATIONAL LABORATORY OPERATED BY UNION CARBIDE CORPORATION - FOR THE DEPARTMENT OF ENERGY 


\section{DISCLAIMER}

This report was prepared as an account of work sponsored by an agency of the United States Government. Neither the United States Government nor any agency Thereof, nor any of their employees, makes any warranty, express or implied, or assumes any legal liability or responsibility for the accuracy, completeness, or usefulness of any information, apparatus, product, or process disclosed, or represents that its use would not infringe privately owned rights. Reference herein to any specific commercial product, process, or service by trade name, trademark, manufacturer, or otherwise does not necessarily constitute or imply its endorsement, recommendation, or favoring by the United States Government or any agency thereof. The views and opinions of authors expressed herein do not necessarily state or reflect those of the United States Government or any agency thereof. 


\section{DISCLAIMER}

Portions of this document may be illegible in electronic image products. Images are produced from the best available original document. 


\section{Printed in the United States of America. Available from}

National Technical Information Service

U.S. Department of Commerce 5285 Port Royal Road, Springfield, Virginia 22161

Price: Printed Copy $\$ 6.00$; Microfiche $\$ 3.00$

This report was prepared as an account of work sponsored by an agency of the United States Government. Neither the United States Government nor any agency thereof, nor any of their employees, contractors, subcontractors, or their employees, makes any warranty, express or implied, nor assumes any legal liability or responsibility for any third party's use or the results of such use of any information, apparatus, product or process disclosed in this report, nor represents that its use by such third party would not infringe privately owned rights. 
ORNL /TM-6310

Contract No. W-7405-eng-26

\section{A MODEL FOR THE MOVEMENT AND DISTRIBUTION OF FISH IN A BODY OF WATER}

D. L. DeAnge 1 is

ENV IRONMENTAL SCIENCES DIVISION

Publication No. 1173

DATE PUBLISHED - JUNE, 1978

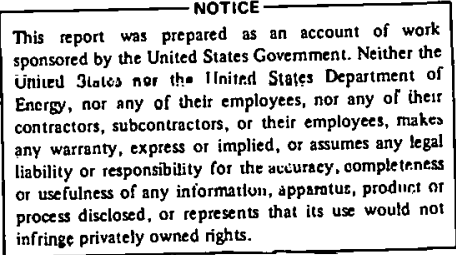

OAK RIDGE NATIONAL LABORATORY

Oak Ridge, Tennessee 37830 operated by UNION CARBIDE CORPORATION

for the

DEPARTMENT OF ENERGY 


\section{THIS PAGE}

\section{WAS INTENTIONALLY LEFT BLANK}




\section{ACKNOWLEDGEMENTS}

I wish to thank Dr. C. C. Coutant for his encouragement and help in this work. I also thank Drs. J. S. Suffern and R. H. Gardner, who have offered many useful criticisms. This work was sponsored by the Division of Biological and Environmental Research, U.S. Department of Energy, under contract W-7405-eng-26 with Union Carbide Corporation. 


\section{THIS PAGE \\ WAS INTENTIONALLY \\ LEFT BLANK}




\section{ABSTRACT}

DEANGELIS, D. L. 1978. A model for the movement and distribution of fish in a body of water. ORNL/TM-6310. Oak Ridge National Laboratory, Oak Ridge, Tennessee. $78 \mathrm{pp}$.

A Monte Car lo mathematical model tracks the movement of fish in a body of water (e.g., a pond or reservoir) which is represented by a two-dimensional grid. For the case of a long, narrow reservoir, depth and length along the reservoir are the logical choices for coordinate axes. In the model, it is assumed that the movement of fish is influenced by gradients of temperature and dissolved oxygen, as well as food availability and habitat preference. The fish takes one spatial "step" at a time, the direction being randomly selected, but also biased by the above factors.

In trial simulations, a large number of simulated fish were allowed to distribute themselves in a hypothetical body of water. Assuming only temperature was influencing the movements of the fish, the resultant distributions are compared with experimental data on lemper ature preferenccs. 
THIS PAGE

\section{WAS INTENTIONALLY \\ LEFT BLANK}


ACKNOWLEDGMENTS . . . . . . . . . . . . . . . . . ABSTRACT ......................... . . . V LIST OF TABLES . . . . . . . . . . . . . . . . . . . . . ix LIST OF FIGURES . . . . . . . . . . . . . . . . . . . . . . . xi GENERAL DESCRIPTION OF THE MODEL . . . . . . . . . . . . . . 4 MATHEMATICAL DESCRIPTION OF THE MODEL . . . . . . . . . . . . . 9 COMPUTER PROGRAM ...................... 16

Part A. Input Cards................. 19

Part B. Output . . . . . . . . . . . . . . . 24

Part C. Computer program listing . . . . . . . . . . 24 TRIAL SIMULATIONS . . . . . . . . . . . . . . . . 28

Fish movements... . . . . . . . . . . . . 28

Fish distribution patterns . . . . . . . . . . . . 28 SUMMARY . . . . . . . . . . . . . . . . . . 37

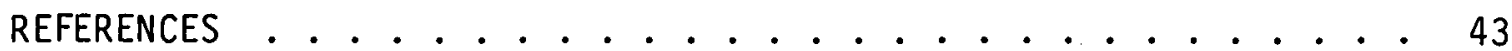

APPENDIX ......................... . . . . . . . . . . . . . 
THIS PAGE

WAS INTENTIONALLY LEFT BLANK 


\section{LIST OF TABLES}






\section{THIS PAGE}

\section{WAS INTENTIONALLY \\ LEFT BLANK}




\section{LIST OF FIGURES}

Figure

1 A hypothetical reservoir. The vertical dimension is depth in meters (disproportionately scaled), and the horizontal dimension is length along the reservoir in kilometers, with the downstream dam at the left. Isotherms in degrees Centrigrade (solid lines) and dissolved oxygen isobars in parts per thousand (dotted lines) are sketched in. The shaded region denotes high food availability. A power plant is assumed located at the upstream end of the reservoir . . . . . . . . . . . 5

2 The point $(i, j)$ in a grid of points, with the adjacent points to which the fish can move in one step....... . 7

3 A grid of points representing a portion of the reservoir. The shaded circles are water, while the open circles are above the water surface. The shaded circles surrounded by 1 arger circles represent points along the preferred temperature isotherm ..................... 8

4 A plot of food availability to fish in a hypothetical reservoir. The peaks and plateaus represent the regions of high food availability.............. . . 18

5 Input data for a sample trial simulation as it appears on the data cards . . . . . . . . . . . . . . . 20

6 Input data for a sample trial simulation as it is printed out by the computer program . . . . . . . . . . . . 25

7 Plot of simulated motions of two fish initially placed at points $A$ and $B$. The assumed preferred temperature is TEMP $_{p}=29.0^{\circ} \mathrm{C}$ and the force of temperature attraction, $\mathrm{P}_{T}$, is 1.0 for case $A$ and 50.0 for case B. . . . . . . . 26

8 The distribution of 500 fish influenced only by temperature in the reservoir after 200 steps. The assumed preferred temperature is $29.0^{\circ} \mathrm{C}$. Other parameters of the model are given in Table 2 . . . . . . . . . . . . . . . 27 
9 Histogram of percent distribution of fish in Fig. 8 about the preferred temperature of $29.0^{\circ} \mathrm{C}$. . . . . 38

10. Histogram of relative frequency of 1 argemouth bass in ambient water temperatures during daytime (from Reynolds and Casterlin 1977) . . . . . . . . . 39

11 The distribution of 500 fish influenced by temperature, dissolved oxygen, food availability and habitat favorability in the reservoir after 200 steps. Parameter values are given in Table 3........... 40 


\section{INTRODUCTION}

The distribution of fish populations in bodies of water is interesting to sportsmen, commercial fishermen, and ecologists alike. Several factors that may influence fish movements and spatial population distribution have been proposed, including temperature, dissolved oxygen in the water, $\mathrm{pH}$ values, the availability of food, the presence of cover for protection from predators, and the occurrence of competitors. These are not all independent. Dissolved oxygen is to some extent related to water temperature, as is the availability of certain types of prey. If the locomotor responses of $f$ ish to each of the factors were known in detail, then one could feasibly predict the average motions of a $f$ ish in a given body of water. The task of identifying and quantifying all the influences on fish locomotor behavior will not be easy, but significant progress has been made, thanks to ingenious laboratory experiments and telemetry methods useful for the field.

As the factors involved in the spatial behavior of fish begin to be understood, it can be applied to a host of practical matters. For example, one would like to know where in a body of water fish population densities will be highest at a given time of year. Also, how will the population distribution in space respond to slow or rapid changes in the condition of the water, either through natural processes such as seasonal variations, or artiffcial changes such as those induced by power plant operations?

Both basic research and practical applications in the area of fish movements will rely on techniques of mathematical modeling. Models incorporating specific hypotheses will form a framework for experimental research, from which the data can be used to test the hypotheses. When the fundamental parameters of the models have been quantified, the model can be used predictively. This report describes a mathematical model capable of being used in conujunction with laboratory experiments and field studies, and later, for predictive purposes. 
Much experimental research has gone into the study of the effects of temperature on locomotor behavior in fishes. Temperature has been called the most important influence on the behavior of many freshwater fish (e.g., Coutant 1975). It has long been noticed that fish move to different areas of a body of water as water temperature changes. For example, largemouth bass overwinter in deep water, where the temperature is warmest. Using underwater telemetry, Warden and Lorio (1973) found that largemouth bass tend to move great distances to new home ranges in spring and $f a l l$, when water temperature is changing most rapidly. In winter, the population of largemouth bass cungregate around the thermal discharges of power plants (Gibbons, Hook and Forniry 1972). In a Texas cooling reservoir, it was noticed that largemouth bass sought out the cooler shoreline zones in sumer mornings when the remainder of the reservoir had temperatures exceeding $37.8^{\circ} \mathrm{C}$ (Smith 1972).

Laboratory studies have been performed to refine the data on temperature selection of several centrarchid species (Reynolds and Caster lin 1976, Stuntz and Magnuson 1976). Researchers have also sought to relate temperature preferenda with thermoregulation and the optimization of physiological processes (e.g., McCauley and Huggins 1976, Reynolds and Casterline 1976). Gruwlh ràtes of larqemulh bass usually seem to be optimal near their temperature preferenda (Coutanl and $\operatorname{Cox} 1976$ ), although this does not seem to be the case for bluegills in thermal discharge areas during the summer months (Kitchell et al. 1974). Bluegills were shown to actively avoid lethal temperatures (Peterson and Schutsky 1976), and to vary their temperature preferenda according to the ir daily rations (Stuntz and Magnuson 1976).

A question that has bearing on attempts to model fish movements is what is the precise merhanism hy which fish terid to center around their preferred temperatures? Neill (1976) discusses different mechanisms in detail and describes one-dimensional computer models based on some of these mechanisms. Thermoregulatory mnvements can be broadly categorized as predictive or reactive. In the former case, the fish is assumed to have some knowledge, by prior experience or instinct, of the 
temperature distribution in the body of water, and will use this knowledge to move toward the desired temperature range. For example, since lower water strata are normally cooler than upper layers, the fish should automatically move downwards when it feels too warm. Reactive behavior presupposes no prior knowledge of the temperature distribution, but only that the fish responds to different temperature regimes by altering its locomotory behavior. Several models of reactive movements have been developed. One type of model has been termed orthokinetic by Fraenkel and Gunn (1961). According to this model, fish slow their movements when in the preferred temperature range, increasing their chances of staying there. Both Fraenkel and Gunn (1961) and Neill (1976) have pointed out the inefficiency of this model for producing aggregation about the preferred temperature. Fish whose direction of motion was originally oriented away from the preferred temperature would continue to move away from it. Neill was able to obtain realistic aggregation on ly when his model specified a high probability of changing directions when the fish was moving away from the preferred temperature range. This form of behavior is called klinokinesis.

Dissolved oxygen and $\mathrm{pH}$ in the water are important to the health of the fish and, therefore, presumably influence its movements. While fish have not been shown to exhibit dissulved oxygen and $\mathrm{pH}$ preferenda, they might be expected to avoid unfavorable conditions. For example, at $25^{\circ} \mathrm{C}$ the minimum oxygen requirement of silall largemouth bass is a lmost $0.92 \mathrm{ppm}$ (Moss and Scott 1961); it would be advantageous for such fish to preferentially move away from areas with dissolved oxygen levels below this minimum.

The movement of fish in response to food availability and habitat preference probably involve learning where favorable conditions exist in a body of water. It is harder to develop models for response to these factors than it is for motion in temperature gradients, since it is difficult to know the extent of learning in the fish.

The model described in this report assumes that the fish acts as if it can sense temperature gradients and will move along a temperature 
gradient in the direction of its preferred temperature. We do not specify whether the fish acts this way because it actually can perceive temperature gradients or because its klinokinetic activity increases as it moves into less preferrable temperature ranges. On the scale length we are dealing with (meters vertically and kilometers horizontally), the precise mechanisms of motion on the small scale may be unimportant. We also assume that the fish will move away from dissolved oxygen levels below that which is the minimum tolerahle, and that they w11l have a general tendency to move toward areas of greater available food and more favorable habitat. These several influences can either reinforce each other or, to some extent, cancel each other under particular circumstances. Aside from these basic assumptions, the model is very general and can be parameterized to suit a variety of situations.

The present model is offered not as a description of the way fish behave, but as a device by which a variety of hypothetical descriptions of locomotor behavior can be tested. A few examples are given to illustrate the way in which the model is used. More thorough exploration of the model will be undertaken later, in combination with field studies.

\section{GENERAL DESCRIPTION OF THE MODEL}

The intent of this model is to predict the average spatial distribution of a fish population in a closed body of water. To do this we simulate the movements of individual fish, allowing a large number of fish to start from random positions in the body of water, and to move for a certain period of time. We assume that a small number of tactors Intluence the movements of the fish; temperature, dissolved oxygen, food availability and habitat preference.

The model is designed to apply to a two-dimensional representation of a hypothetical reservoir (Fig. 1). The two dimensions are depth and either length along the reservoir or width across a cross section. A three-dimensional representation would be preferable, but would pose 


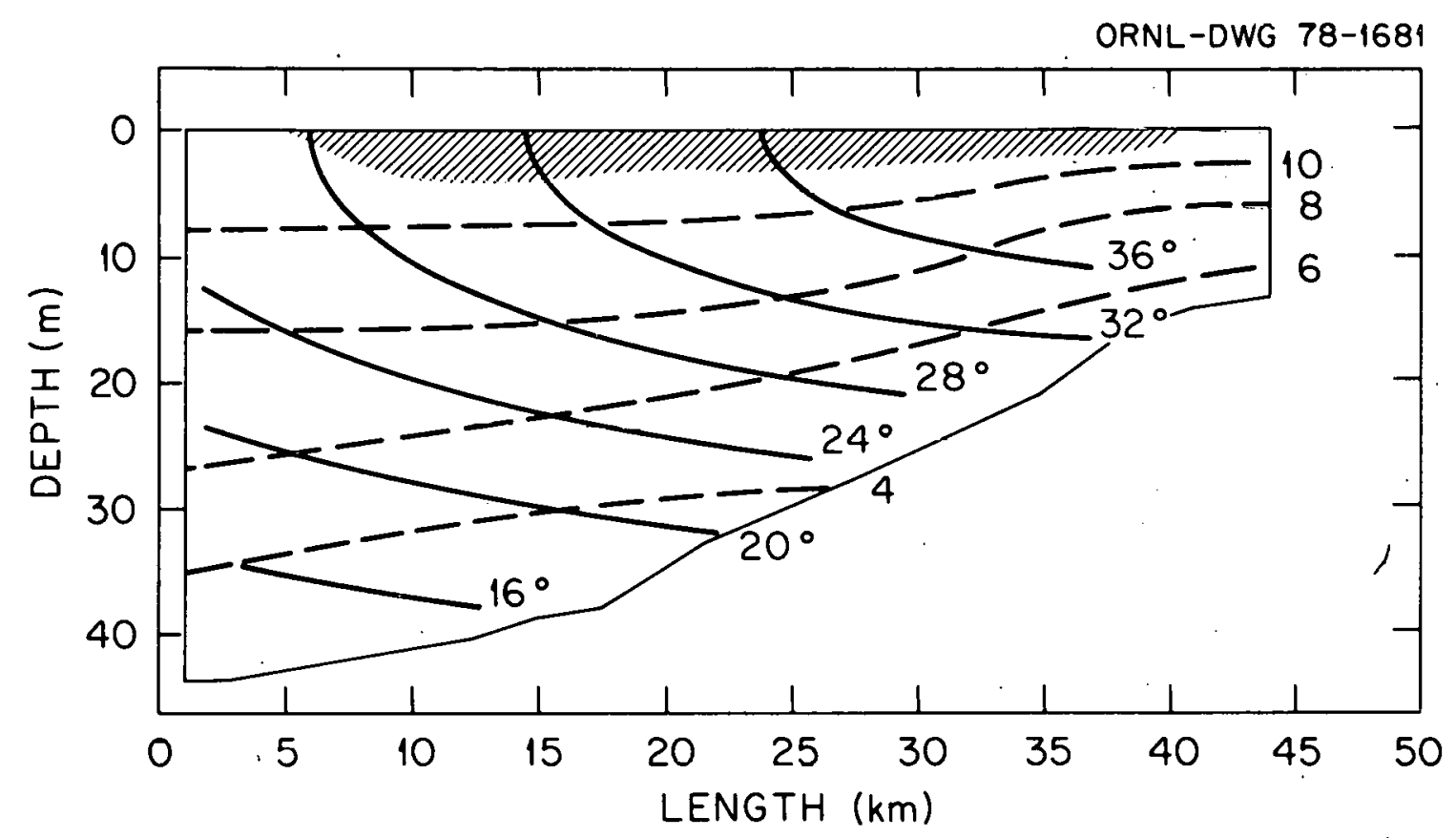

Fig. 1. A hypothetical reservoir. The vertical dimension is depth in meters (disproportionately scaled), and the horizontal dimension is length along the reservoir in kilometers, with the downstream dam at the left. Isulherms in dogrees Centrigrade (solid lines) and dissolved oxygen isobars in parts per thousand (dotted lines) are sketched in. The shaded region denotes high food availability. A power plant is assumed located at the upstream end of the reservoir. 
problems both computationally and graphically. It is hoped that this model will eventually be extended to three dimensions, but the present two-dimensional model is useful. Note that the scaling in the vertical (depth) dimension is greatly exaggerated relative to the horizontal coordinate. Typical temperature and dissolved oxygen isoclines are sketched in, and the area in which food availability is greatest (usually the shallow water along shore lines) is shaded. We assume that the position of those factors are stable over the time scale in which a fish can move considerable distances. A typical fish will have a preferred range of temperatures, will tend to avoid very low levels of dissolved oxygen, will be attracted by high food availability, and will prefer habitats that give it sufficient cover from predators. On this basis, the average distribution of a model fish population may be reliably predicted, though the path of a given fish is unique.

For modeling purposes, it is necessary to represent the two-dimensional space by a grid of points. Consider a fish located at some point $(i, j)$ in the grid points (Fig. 2$)$. The fish can move to one of eight adjacent points $(i+\delta, j+\varepsilon)$, where $\delta$ and $\varepsilon$ take on the values

1,0 and +1 (but both cannot be 0 simultaneous $1 y$ ). It is assumed that the following factors influence the next. location of the fish:

1. The tendency of the fish to continue moving in the general directiun In which it is already moving. This can be termed the "forward inertia" of motion.

2. The preferred temperature of the fish and the temperature at the present location of the $f i s h,(i, j)$, and the eight surrounding points.

3. The location of food supplies and cover.

4. The boundary of the water hody, which sets limits on the motion of the fish.

These factors can be elucidated to some extent by examination of Fig. 3. Assume the fish is located at point $(i, j)$ and has just moved rrum the point $(i, j-1)$. The black points in this figure are those in the body of water while the white dots are above its surface. The isotherm of the preferred temperature is represented by black dots 
ORNL-DWG 77-2861

$$
(i-1, j+1)
$$

$(i+1, j+1)$

$$
(i-1, j)
$$

$(i, j)$
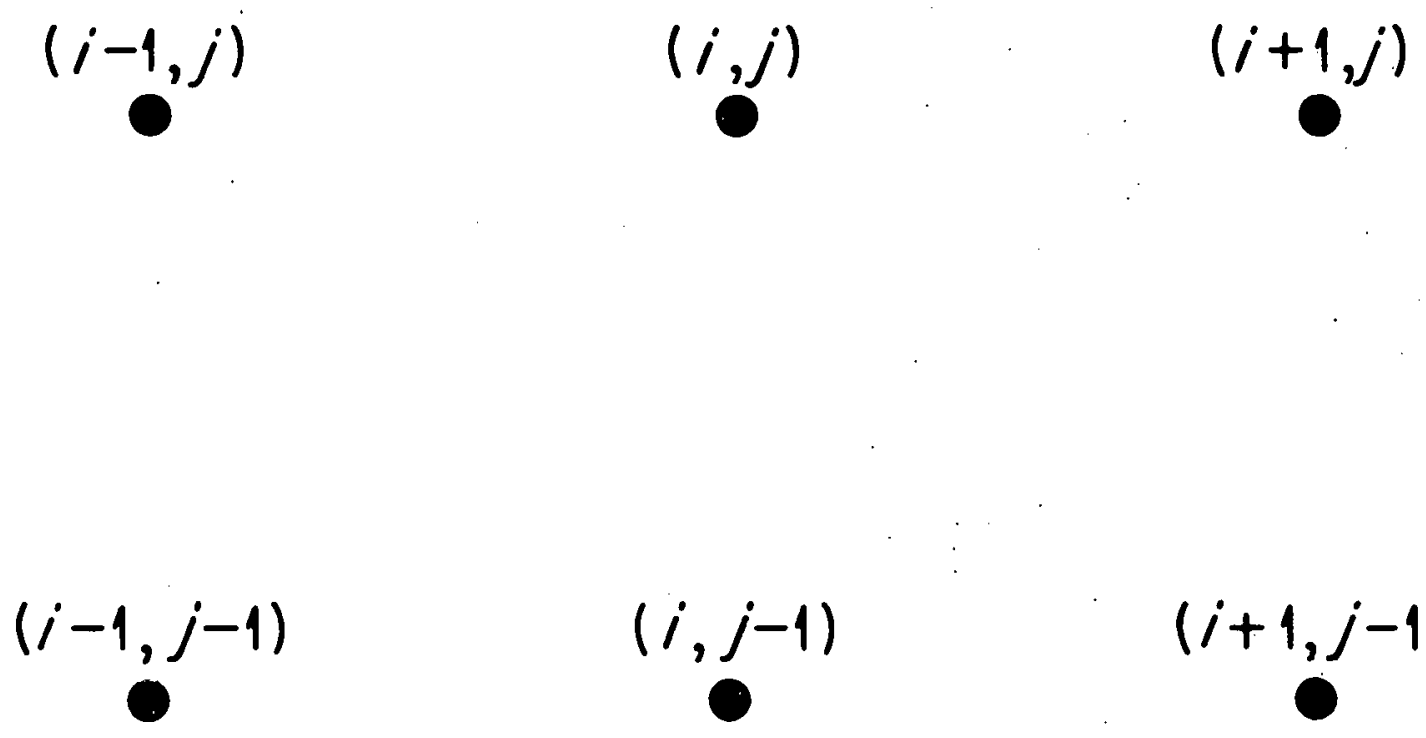

$(i+1, j-1)$

Fig. 2. The point $(i, j)$ in a grid of points, with the adjacent points to which the fish can move in one step. 


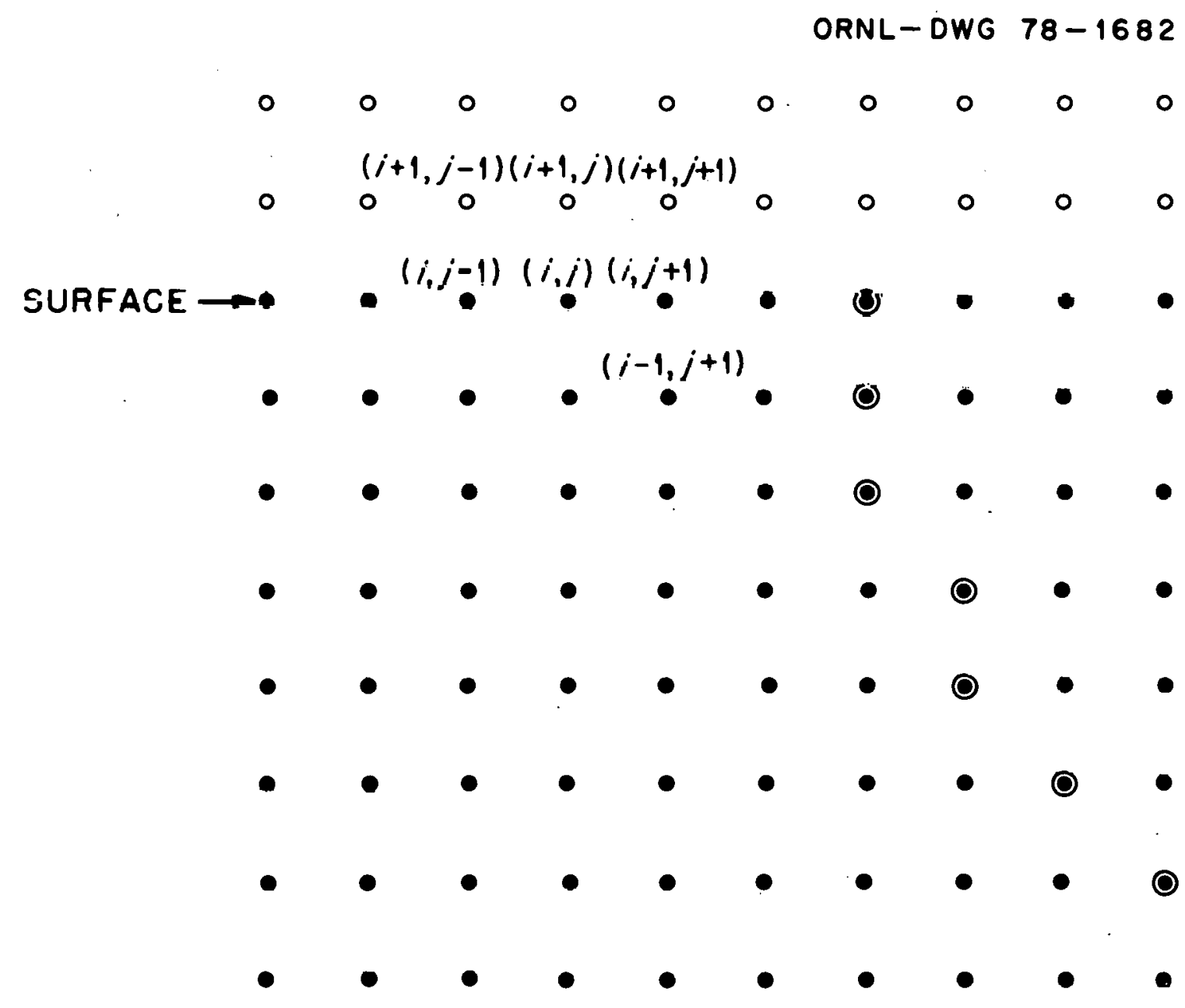

Fig. 3. A grid of points representing a portion of the reservoir. The shaded circles are water, while the open circles are above the water surface. The shaded circles surrounded by larger circles represent points along the preferred teiniperature isotherms. 
surrounded by a circle. The most likely next "step" of the fịs is to the point $(i, j+1)$, since this is in its direction of preferred temperature as well as its direction of inertia. The fish also has a high probability of moving to point $(i-1, j+1)$. Of course, the fish cannot move to points $(i+1, j-1),(i+1, j)$, or $(i+1, j+1)$ because these lie above the surface of the water.

It is conceptually and mathematically advantageous to discuss fish movements in terms of the four factors listed above, but these factors have not been quantified in detail (except for factor 4; the fish we are dealing with cannot normally leave the water). Data are available on the response of some fish species to temperature and dissolved oxycjen variations, but other factors, such as food availability and habitat preferences, complicate the situation in natural bodies of water, making predictions based on mathematical models less reliable.

\section{MATHEMATICAL DESCRIPTION OF THE MODEL}

It is convenient to represent the probability of a fish moving one step from a point $(i, j)$ to another $(k, m)$ in a two-dimensional grid as an element of a transition matrix, $P_{i j, k m}$. Since the fish can move from one grid point only to an adjacent one in a single step; $k$ and $m$ are constrained as follows:

$$
\begin{aligned}
& k=i+\delta \quad(\delta=-1,0,+1) \\
& m=j+\varepsilon \quad(\varepsilon=-1,0,+1),
\end{aligned}
$$

(see Fig. 1). In all future discussion, $k$ and $m$ will be implicitly subject to the limitations $(1 a, 1 b)$.

The sum over all probabilities for direction of motion must equal unity: 


$$
\sum_{k=i-1}^{i+1} \underset{\sum}{j=j-1} P_{i j, k m}=1.0
$$

The model is event-oriented, where an event is a step in space. This means that, given a fish initially at point $(i, j)$, the next moment of interest occurs only when the fish has moved to an adjacent grid point. Therefore, the probability of the fish being in its same position at the next locomotory event in the model is identically zero, or

$$
P_{i j, i j}=0.0
$$

All of the transition elements together define a transition matrix, $\underline{\text { P. Let }} \underline{x}(1)$ be the probability vector for the position of the fish at a given moment. The elements of $\underline{x}(1)$, which are $x_{i j}(1)$, represent the probabilities of the fish being located at any given point $(i, j)$. The condition

$$
\sum_{i=-\infty}^{+\infty} \sum_{j=-\infty}^{+\infty} x_{i j}(1)=1.0
$$

must hold since the fish must be somewhere in the water body. Then

$$
\underline{x}(2)=\sum_{j=m-1}^{m+1} \sum_{i=k-1}^{k+1} x_{i j} P_{i j, k m}=\underline{P} \cdot \underline{x}(1)
$$


is the probability matrix for the position of the fish after its next movement to a new grid point.

If the movement of the fish from one grid point to the next is purely random (i.e., "random walk"), then

$$
P_{i j, \mathrm{~km}}=1.0 / 8.0=0.125 ;
$$

that is, there is an equal probability of 0.125 of the fish going to any of the eight adjacent points. However, the motion of the fish is biased by its forward inertia, temperature and dissolved oxygen gradients, the location of food and favored habitat, and boundaries of the body of water.

Consider first only the influence of forward inertia. It introduces a directional bias on top of random motion. The transition probability can be written

$$
P_{i j, k m}=\{1.0+I(k, m)\} / \xi,
$$

where $\xi$ is the normalization factor,

$$
\xi=\sum_{k=i-1}^{i+1} \sum_{m=j-1}^{j+1} P^{\prime}{ }_{i j, k m},
$$

and

$$
\begin{gathered}
P_{i j, i j}^{\prime}=0.0 \\
P_{i j, k m}=1.0+I(k, m) \quad(m \neq j, \text { if } k=i) .
\end{gathered}
$$


The term $I(k, m)$ is a measure of the strength of forward inertia relative to random effects in determining the next grid point in the fish's course of movement. If $I(k, m) \ll 1.0$, then the random effects dominate the movement. On the other hand, if, say, $I(i+1, j+1)>1.0$ and $I(i+1, j+1) \gg I(k, m)$ for a 11 seven other pertinent values of $k$ and $m$, then the fish is likely to move upward and to the right on its next step. The magnitude of $I(k, m)$ for particular values of $k$ and $m$ depends on the past motion of the fish. For this reason, $\underline{P}$ is not a Markov process matrix.

In a similar manner, the effects of temperalure and dissolved oxygen can be incorporated into this mathematical scheme. If $T(k, i n)$, $D O(k, m), F(k, m)$ and $H(k, \dot{m})$ represent the strengths with which temperature gradients, dissolved oxygen gradients and gradients in distribution of food availability and habitat desirability, respectively, then one can write

$p_{i j, k m}=\cdot\{1.0+I(k, m)+T(k, m)+D 0(k, m)+F(k, m)+H(k, m)\} / \xi$

where $\xi$ is defined by Eq. (8) and now

$$
p^{\prime}{ }_{i j, k m}=1.0+1(k, m)+T(k, m) 1 D 0(k, m)+F(k, m)+H(k, m) .
$$

The effects of the boundary of the body of water on fish movement is incorporated as rollows. Define $B(k, m)$ as the boundary ractor, and now wr ite $p_{i j, k m}$ as

$p_{i j, k m}=\{1.0+I(k, m)+T(k, m)+D O(k, m)+r(k, m)+H(k, m)\} B(k, m) / \zeta$,

where $\xi$ is defined by Eq. (8) and now

$P^{\prime}{ }_{i j, k m}=\{1.0+I(k, m)+T(k, m)+D 0(k, m)+F(k, m)+H(k, m)\} B(k, m)$, 
where

$$
B(k, m)= \begin{cases}1, & (k, m) \text { in the body of water } \\ 0, & (k, m) \text { outside the body of water }\end{cases}
$$

It is now appropriate to discuss the detailed formulations of $I(k, m), T(k, m), D)(k, m), F(k, m)$ and $H(k, m)$. These are developed in as simple and practical a manner as possible in the absence of definitive field measurements. Subsequent studies may require alterations of these formulations.

Inertia of forward movement, $I(k, m)$

Assume the fish is at point $(i, j)$ and its preceding location was $\left(i^{\prime}, j^{\prime}\right)$, where

$$
\begin{aligned}
& j=i^{\prime}+\delta^{\prime} \\
& j=j^{\prime}+\varepsilon^{\prime},
\end{aligned}
$$

and where $\delta^{\prime}$ and $\varepsilon^{\prime}$ have the same ranges of values as $\delta$ and $\varepsilon$ [see Eqs. $(1 a, 1 b)]$. Then $I(k, m)$, where $k$ and $m$ are given by Eqs. $(1 a, 1 b)$, is $a$ conditional probability,

$$
I(k, m)=\operatorname{Probability}\left(\delta, \varepsilon \text { given } \delta^{\prime}, \varepsilon^{\prime}\right) \text {, }
$$

where this probability is higher the more positive the correlation between $(\delta, \varepsilon)$ and $\left(\delta^{\prime}, \varepsilon^{\prime}\right)$. In the model, a quantity, $C$, is defined, where,

$$
C=\left|\delta-\delta^{\prime}\right|+\left|\varepsilon-\varepsilon^{\prime}\right| \text {. }
$$


The bars represent absolute values of the enclosed differences. The quantity $C$ can take on one of five different integer values, for each of which $I(k, m)$ is assigned a different value, $e_{j}$, as represented in Eq. (18),

$$
I(k, m)= \begin{cases}e_{1} & (c=0) \\ e_{2} & (c=1) \\ e_{3} & (c=2) \\ e_{4} & (c=3) \\ e_{5} & (c=4),\end{cases}
$$

where the constants $e_{i}$ are chosen so that $e_{1}>e_{2}>e_{3}>e_{4}>$ $e_{5}$. The model fish is likely to continue in the same general direction because $I(k, m)$ is greatest when $\delta=\delta^{\prime}$ and $\varepsilon=\varepsilon^{\prime}$.

Temperature term, $T(k, m)$

Assume the fish has a preferred temperature, TEMP ${ }_{p}$. The temperature at point $(i, j)$ is defined as $\operatorname{TEMP}(i, j)$. Define the absolute difference between the temperature at $(i, j)$ drid the optimal temperature by $d_{T}(i, j)=\left|\operatorname{TEMP}(i, j)-\operatorname{TEMP}_{p}\right|$. Then, if $(k, m)$ is a neighboring point of $(i, j)$, we define the temperature effect, $T(k, m)$, by

$$
T(k, m)=\left\{\begin{array}{rr}
s_{T}>0.0 & d_{T}(k, m)<d_{T}(i, j) \\
0.0 & d_{T}(k, m) \because d_{T}(i, j) .
\end{array}\right.
$$

The quantitative value of the constant $s_{T}$ is assigned to reflect the strength of the effect of the temperature gradient on the fish. Estimates of values might be obtained from experiments in which only temperature effects are present. 
Dissolved oxygen term, DO $(k, m)$

We have no information on the existence of a "preferred" DO level, but there is evidence on minimum tolerable levels. Define by DISOX ${ }_{\text {min }}$ the min imum tolerable level and by $\operatorname{DISOX}(i, j)$ the dissolved oxygen at point $(i, j)$. Then if the fish is in a spatial region in which the dissolved oxygen is below the minimum tolerable limit, (i.e., $\left.\operatorname{DISOX}(i, j)<\operatorname{DISOX}_{\min }\right)$, then define the dissolved oxygen effect, $D 0(k, m)$, by

$$
D O(k, m)=\left\{\begin{aligned}
S_{D O}>0.0 & \operatorname{DISOX}(k, m)>\operatorname{DISOX}(i, j) \\
0.0 & \operatorname{DISOX}(k, m)<\operatorname{DISOX}(i, j) .
\end{aligned}\right.
$$

If the fish is in a region in which the amount of dissolved oxygen in the water is above the minimum tolerable limit, then $D O(k, m)=0$ for all values of $k$ and $m$. The constant $S_{D O}$ is a measure of the strength of avoidance by fish of low dissolved oxygen levels.

Food availability terms, $F_{q}(k, m)$

Assume that there are $q$ regions in the body of water that are attractive to fish because of high food availability. We assume that the closest of these to the current position of the fish will exerl some attraction on the fish. Define by $d_{F, q}(i, j)$ the level of food availability at point $(i, j)$. Then if $(k, m)$ is a point neighboring $(i, j)$, the force of attraction of the food is

$$
F_{q}(k, m)=\left\{\begin{array}{rr}
s_{F, q}>0.0 & d_{F, q}(k, m)<d_{F, q}(i, j) \\
0.0 & d_{F, q}(k, m)>d_{F, q}(i, j) .
\end{array}\right.
$$


Habitat preference terms, $H_{q}(k, m)$

Assume that there are $\bar{P}$ regions in the body of water that are attractive to fish because of their favorability as habitat. We assume that the closest of these to the current position of the fish will exert some attraction on the fish. Define by $d_{H, p}(i, j)$ the level of habitat favorability at point $(i, j)$. Then if $(k, m)$ is a point neighboring $(i, j)$, the force of attraction of habitat is

$$
H_{p}(k, m)=\left\{\begin{aligned}
s_{H, p}>0.0 & d_{H, p}(k, m)<d_{H, p}(i, j) \\
0.0 & A_{H, p}(k, m)>d_{H, p}(i, j) .
\end{aligned}\right.
$$

COMPUTER PROGRAM

The computer program consists of a MAIN PROGRAM and three subroutines, SUBROUTINE RANSET, FUNCTION URAND, SUBROUTINE PLOTT and SUBROUTINE HIST.

The MAIN PROGRAM first reads in the input data, which is described in Part $A$ below, and then prints 1t out (see Part B, beluw). There are two ways in which data on temperature and dissolved oxygen can be entered; either by specifying each grid point values, or by using mathematical functions to express their spatial variation. As an example of the latter, temperature might be given by the function

$$
\text { TEMP }=40000 . /\left\{10000 .+(i-85 .)^{2}+5.0(j-55 .)^{2}\right\} \text {, }
$$

which leads to the isotherms shown in Fig. 1. Similar functions are used for dissolved oxygen. Food distribution might be modeled by functions of the form

$$
\mathrm{FOOD}_{\mathrm{q}}=F_{D} /\left(1.0+1.0 \exp \left\{-\alpha\left(i-F_{F q}\right)^{2}-B_{F q}\left(j-F_{q}\right)^{2}\right\}\right),
$$


which are plotted in Fig. 4. The peaks and plateaus in this figure represent regions of high food availability. Similar functions are used to describe habitat preferences.

In the input data, the user specifies how many fish are released at random locations in the body of water and how many spatial steps they are allowed to take. The user also chooses whether or not the paths of the fish are to be plotted. If they are not, only the final positions of the fish will be shown by a dot. The user can also have the computer print out the isotherms, if desired.

The program first randomly selects, using a pseudo-random number generator, the position and direction of motion of the fish. Thereafter, the movement of the fish from point to point on the grid is determined by the pseudo-random number generator, in combination with the transition probabilities, $p_{i j, k m}$, which are computed at each step. Information on the paths and final positions of the fish is stored for later printing.

The on ly purpose of SUBROUTINE RANSET and FUNCTION URAND is to generate pseudo-random numbers on the interval $(0,1)$. These subroutines have been described elsewhere (McGarth and Irving, 1975) and so will not be discussed here. The type of simulation that uses a pseudorandom number generator is commonly referred to as a Monte Carlo simulation. SUBROUTINE PLOTT handles the plotting of the outline of the body of water, while SUBROUTINE HIST plots a histogram of the final temperature distribution of the fish.

The computer program is meant to be very general. If changes in the program are necessary, however, the documentation of the program below should be complete enough to enable the user to make these changes.

The remainder of this section consists of a description of the data input cards ( $P$ art $A$ ), the printed output of the program (Part B), and a listing of the computer program (Part $C$ ). In the next section, the use of the program is demonstrated by means of some trial simulations. 
ORNL-DWG $78-2644$

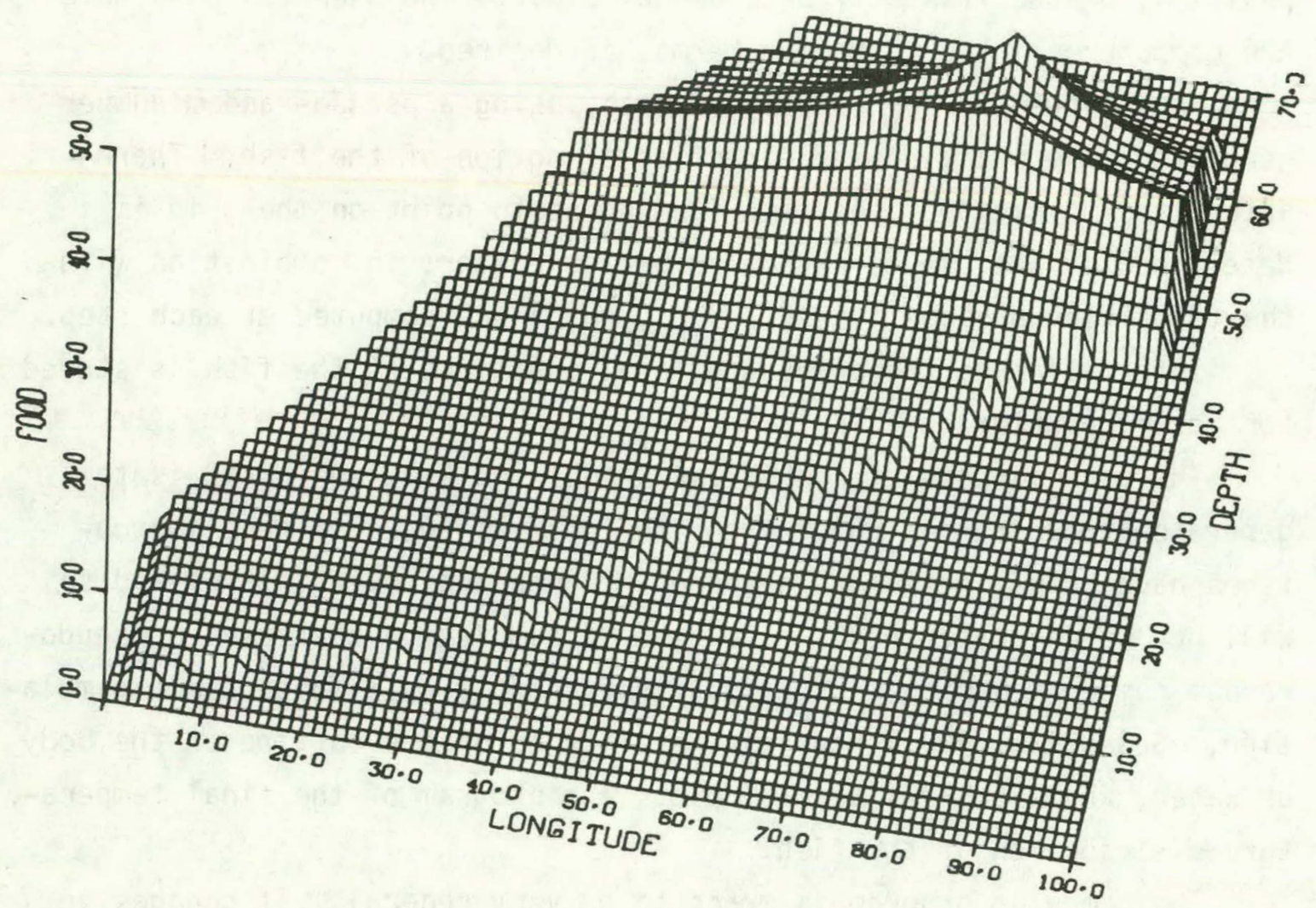

Fig. 1. A plot of fond availability to fish in a hypothetical reservoir. The peaks and plateaus represent the regions of high food availability. 
Part A. Input Cards

Figure 5 is a listing of the input cards relevant to an example given in the next section. These input cards are described below:

\section{Card A}

Input parameters: NHOR, NVER, NREG

Format: 4 I5

NHOR = number of horizontal grid points

NVER = number of vertical grid points

NREL $=$ number of environmental regions (usually there will be only two; (1) the body of water, and (2) the surrounding air and land

Card B

Input parameters: NREGP

Format: I5

NREGP = the number of points on the line to be drawn to define the boundary of the body of water

Card Set $C$

Input parameters: (ARRAYX (I), I=1, NREGP)

Format: $7 E 10.0$

ARRAYX (I) = the horizontal coordinates of points on the line defining the boundary of the body of water

Card Set D

Input parameters: (ARRAYY (I), I=I, NREGP)

Format: $7 E 10.0$

ARRAYY $(I)=$ the vertical conrdinates of points on the line defining the boundary of the body of water

\section{Card Set $\mathrm{E}$}

Input parameters: NVER cards containing the information IREG, (IBEG(I), IEND(I), TYPE(I), I=1, IREG)

Format: I2, 8X, 6(2I2, F5.1,1X) 


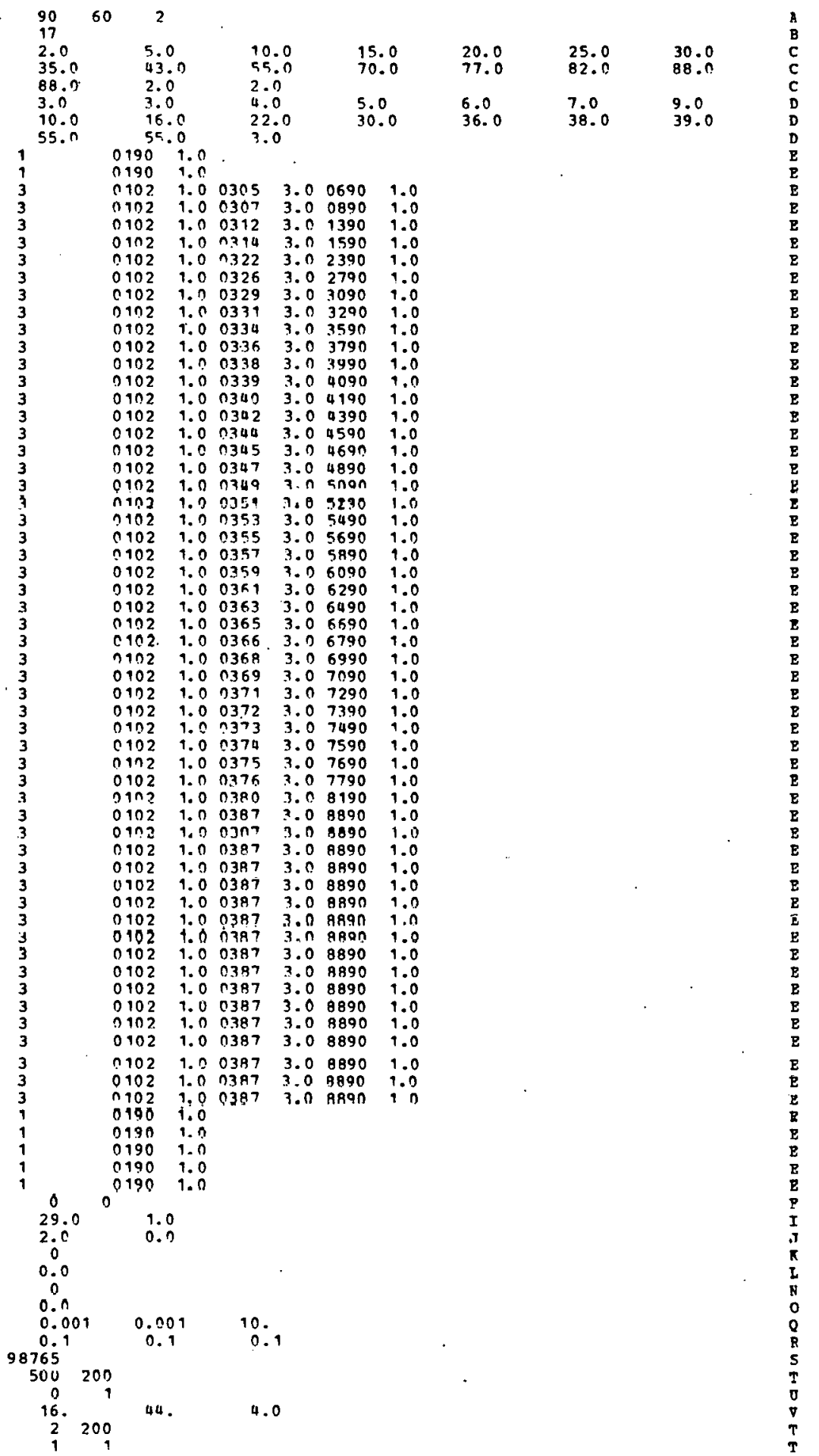

Fig. 5. Input data for a sample trial simulation as it appears on the data cards. 
IREG = number of different environmental types along a given line of grid points

IBEG(I) = the horizontal coordinate of the first grid point of a particular environmental type along a given horizontal line

$\operatorname{IEND}(I)=$ The horizontal coordinate of the last grid point of a particular environmental type along a given horizontal line

TYPE $(I)=$ a numerical label attached to each environmental type to distinguish if from others

Card $\mathrm{F}$

Input parameters: ITEM, IDISOX

Format: $2 \mathrm{I} 5$

ITEM = 0 if spatial temperature data is given by an equation in the program

$=1$ of spatial temperature data is read in point by point

IDISOX $=0$ if spatial dissolved oxygen is given by an equation in the program

$=1$ if spatial dissolved oxygen data is read in point by point

Card Set $G$ (included only if ITEM $=1$ )

Input parameters: (TEMPA(I,J), I=1, NHOR), J=1, NVER

Format: $7 E 10.0$

$\operatorname{TEMPA}(I, J)=$ temperature at grid point $(I, J)$

Card Set $H$ (included only if IDISOX $=1$ )

Input parameters: (DISOX(I,J), I=1, NHOR), J=1, NVER

Format: $7 E 10.0$

$\operatorname{DISOX}(I, J)=$ dissolved oxygen level at grid point $(I, J)$

Card I

Input parameters: TEMPRF, TEMFOR

Format: $2 E 10.0$

TEMPFR = preferred temperature of fish

TEMFOR = force of attraction of preferred temperature of fish 
Card $\mathrm{J}$

Input parameters: DOXMIN, DOXFOR

Format: $2 \mathrm{E} 10.0$

DOXMIN = minimum tolerable dissolved oxygen level for fish

DOXFOR = attractive force of higher dissolved oxygen levels on fish

Card K

Input parameter: NFOOD

Fnrmat: I5

NFOOD - number uf centers of high food availability

Card L

Input parameter: FDATCT

Format: $E 10.0$

FDATCT = force of attraction of food availability on fish movements

\section{Card Set $M$}

Input parameters: $\operatorname{FDNUM(I),FDALP(I),FDBET(I),FDIQ(I),FDJQ(I)~}$

Format: $5 \mathrm{E} 10.0$

TDNUM(I)

FDALP(I) parametors describing spatial dislrlbutions ot

$\operatorname{FDBET}(I)=$ food about each of the centers of food

FDIQ( I) availability (see Eq. 24 and Table 1)

FD.JQ(I)

\section{Card N}

Input parameter: NHAB

Format: IJ

NHAB = number of centers of high habitat favorability

Card 0

Input parameter: HBATCT

Format: $E 10.0$

HBATCT = force of attraction of habitat favorability on fish movements 


\section{Card Set $P$}

Input parameters: $\operatorname{HBNUM}(I), \operatorname{HBALP}(I), \operatorname{HBBET}(I), \operatorname{HBIQ}(\mathrm{I}), \mathrm{HBJQ}(\mathrm{I})$

Format: $5 \mathrm{E} 10.0$

$\operatorname{HBNUM}(\mathrm{I})$

HBALP (I)

parameters describing the spatial distribution

$\operatorname{HBBET}(I)=$ of habitat favorability about the high habitat

$\mathrm{HBIQ}$ (I)

$\mathrm{HBJQ}(\mathrm{I})$ favorability centers (analogous to Eq. (24); also see Table 1 for definitions)

\section{Card Set $Q$}

Input parameters: RES(I), I=1, NREG

Format: $7 E 10.0$

$\operatorname{RES}(I)$ = boundary crossing factors (causing fish to remain in the body of water)

\section{Card R}

Input parameters: $\operatorname{ERTIA(I),~I=1,5}$

Format: $5 E 10.0$

$\operatorname{ERTIA}(I)=$ Inertia of forward motion, $e_{j}$ (see Eq. 18)

\section{Card S}

Input parameter: IX

Format: I5

IX = pseudo-random number generator initilization or "seed". It must be an odd integer. A different value of IX should be used each time the program is run

\section{Card T}

Input parameters: NFISH, NSTEP

Format: 215

NFISH = number of fish considered in the body of water

NSTEP = number of steps in space each fish is allowed to take 
Card U

Input parameters: IPLOT, ISOTH.

Format: 2 I5

IPLOT = 1 if the fish paths are to be plotted, 0 otherwise

ISOTH = 1 if the isotherms are to be plotted, 0 otherwise

Card V

Input parameters: TEML, TEMH, TEMINT

Format: $\quad 3 F 10.0$

TEML = minimum isotherm to be plotted

TEMH = maximum isotherm to be plotted

TEMINT = width of intervals between isotherms

Part B. Output

The printed output consists of two parts. First, the input data is printed out (Fig. 6). Second, a schemata of the body of water is plotted, into which fish paths or spatial population distribution are plotted (Figs. 7 and 8 ). The plotting is done using the DISSPLA graphics package (Integrated Software Systems Corporation 1970) which is available at many computer installations. Programming changes would be necessary to adapt the prngram to other graphics packagcs.

Part C. Computer program details

The complete computer program listing is printed in the Appendix. The comment cards interspersed through the program should enable the user to understand its general design. However, some additional comments inay be useful.

1. The arrays are dimensioned to permit a maximum of $90 \times 60$ grid points at present. This can be changed if desired.

2. A typical run dispersing 500 fish takes about 3 minutes of CPU time in the IBM $360 / 91$ computer, although this changes to some extent as some of the model parameters are varied. The GO step uses less than $230 \mathrm{~K}$ of computer core. 
FISH MOVEMENT IN A BODY CF WATER

NUMBER OF HORIZONTAL GRID POINTS, NHOR $=90$

NUMBER OF VERTICAL GRID POINTS, NVER $=60$

NUMBER OF ENVIRONMENTAL REGIONS, NREG $=2$

TEMPERATUR E IS DESCRIBED BY A MATHEMATICAL FU NCTION

DISSOLVED OXYGEN aMOONTS DESCRIBED BY A MATHEMATICAL FUNCTION

PREFERRED TEMPERATURE, TEMRRF = 29.0000

FORCE OF ATTRACTION OF FREFERFED TEMPERATURE, TEMPOR $=1.0000$

MIN IMUM TOLERABLE DISSOLVED OXYGEN LEVFL, DOXHIN $=\quad 2.0000$

FORCE OP ATTRACTION OF HIGHER DISSOLVED OXYGEN LEVELS $=\mathbf{0 . 0}$

FORCE OP ATTRACTION OP GREATER FOOD AVAILABILITY, FDATCT $=0.0$ $N$ POOD $=0$

FORCE OF ATTRACTION OF HABITAT PREFERENCES, HBATCT $=0.0$, $N H A B=0$

ROUNDARY CROSSING PACTCES, RES(I) $=0.0010 .001$

VALUES OP FORHARD INERTIA, ERIIA $=0.10 \quad 0.10 \quad 0.10 \quad 0.0 \quad 0.0$

RAN DOM NUHBER INITIATOR, IX $=98765$

NUMBER OF FISH IN BODY OF WATER, NFISH $=500$

NUMBER OF STEPS EACH FISH, IS AIINW TO TAKE, NSTEPS = 200

I SOTHERHS ARE YLUT'TED

MINIMUM ISCTHER PIOTTED, TEML $=16.0000$

MAXIMUM ISOTHERM PLOTTEE, TEMH $=44.0000$

DI STANCE BETWEEN ISOTHERMS, TEHINT $=4.0000$

Fig. 6. Input data for a sample trial simulation as it is printed out by the computer program. 


\section{FISH DISTRIBUTION}

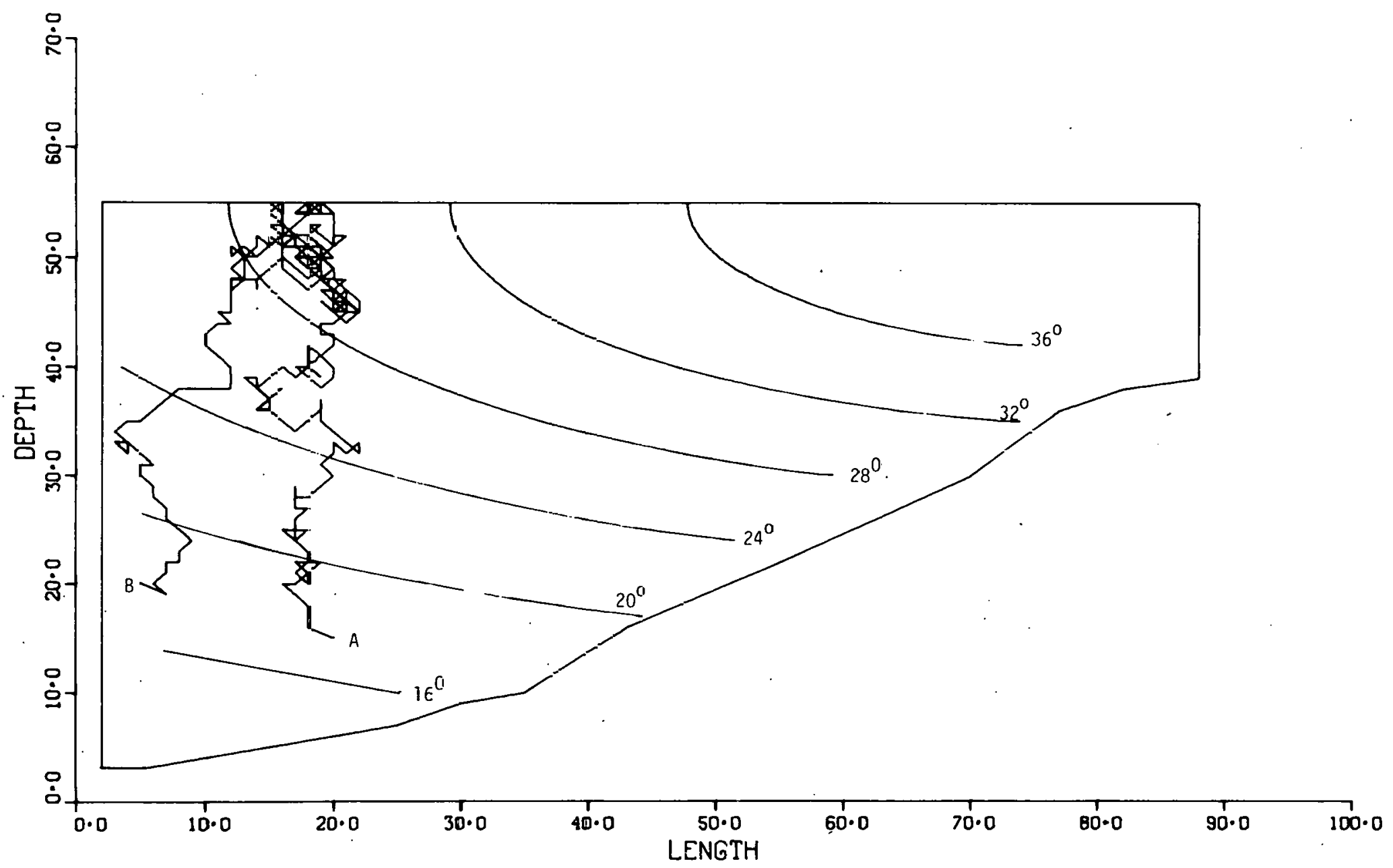

Fig. 7. Plot of simulated motions of two fish initially placed at points $A$ and $B$. The assumed preferred temperature is $\operatorname{TEMP}_{\mathrm{p}}=29.0^{\circ} \mathrm{C}$ ard the force of temperature attraction, $\mathrm{p}_{\mathrm{T}}$, is 1.0 for case $A$ and 50.0 for case $B$. 


\section{FISH DISTRIBUTION}

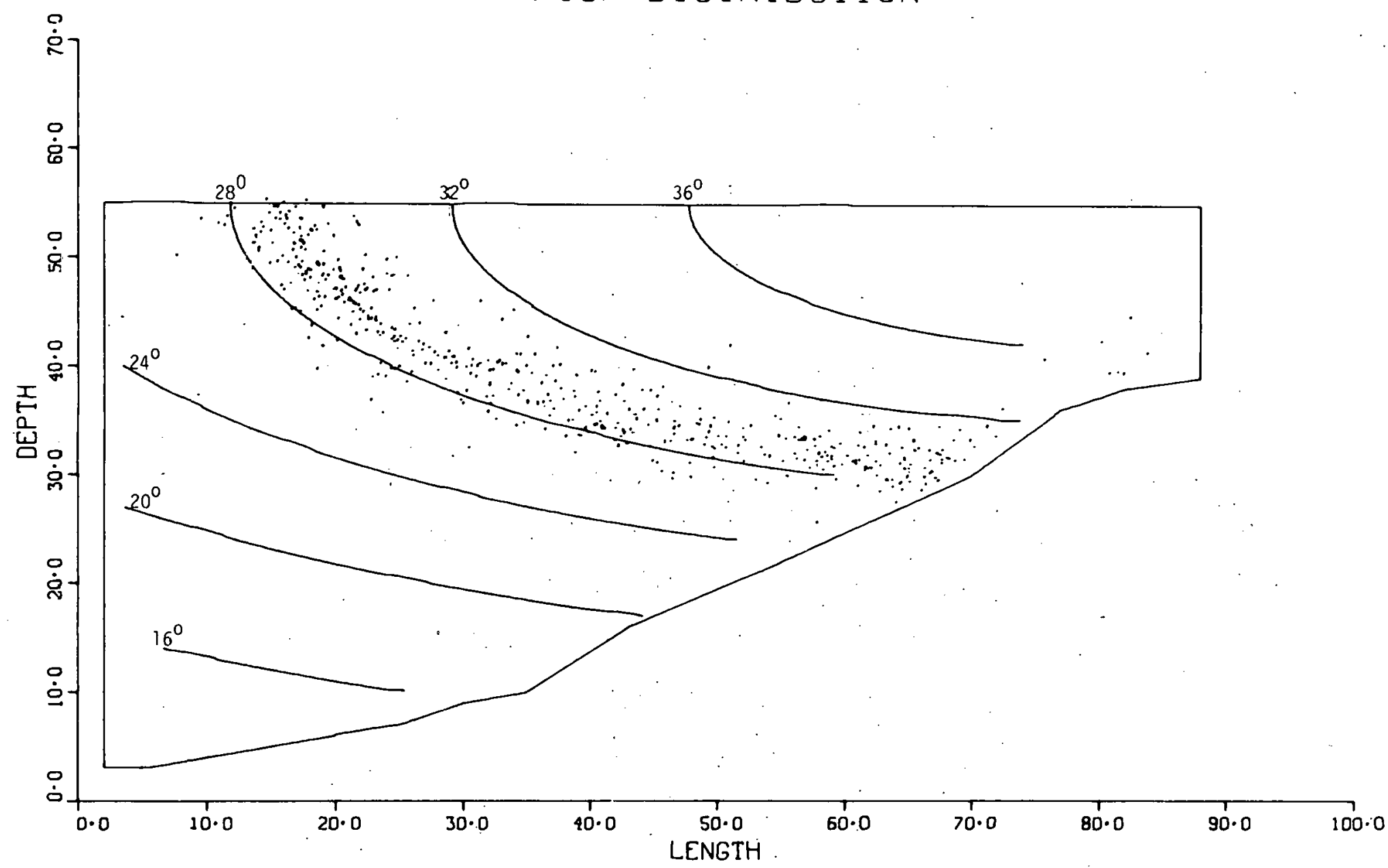

Fig. 8. The distribution of 500 fish influenced only by temperature in the reservoir after 200 steps. The assumed preferred temperature is $29.0^{\circ} \mathrm{C}$. Other parameters of the model are given in Table 2. 
Table 1 is a compilation of the principal FORTRAN variables in the computer program. The equivalent mathematical symbols, of any, and definitions are given as well.

\section{TRIAL SIMULATIONS}

The fundamental question that must be asked of this model is how accurately it can simulate the movements of individual fish and the spatial distribution patterns of populations of fish. There is not enough data on either of these phenomena in natural environments to allow parameters for a model to be thoroughly tested. However. laboratory experiments provide some data on fish distributions in environments in which only thermal effects are important. We shall focus on the thermal influences on the fish in our model and only briefly note how the other factors influence fish distributions in space.

\section{Fish Movements}

Consider the reservoir pictured in Fig. 7, with only the temperature gradient assumed to have an effect on the fish. The temperature isoclines are given by $\mathrm{Eq}$. (23) and the remaining parameters of the model are given in Table 2. A simulated fish is placed in the reservoir at the position $A$; it moves, with a fair amount of meandering, toward the preferred temperature, $\mathrm{TEMP}_{\mathrm{p}}=29.0^{\circ} \mathrm{C}$. The amount of meandering can be decreased by increasing the force of the temperature gradient on the fish movement; that is, by increasing $p_{T}$. When $p_{T}$ is increased from $p_{T}=1.0$ to $p_{T}=50$., and a fish is released at point $B$, it moves more directly toward the preferred temperature.

\section{Fish Distribution Patterns}

Allow 500 fish to be released at randomly selected initial positions in the body of water, and to move in response to temperature gradients only. After 200 steps, they have all had a chance to respond 
Table 1. Principal program variables

\begin{tabular}{|c|c|c|c|}
\hline $\begin{array}{l}\text { Fortran } \\
\text { variable } \\
\text { name }\end{array}$ & $\begin{array}{l}\text { Dimension } \\
\text { (if array) }\end{array}$ & $\begin{array}{c}\text { Mathematical } \\
\text { symbol }\end{array}$ & Definition \\
\hline ARAX & (50) & & $\begin{array}{l}\text { Storage array for horizontal coordinates of } \\
\text { isotherm curves for later plotting }\end{array}$ \\
\hline ARAY & (50) & & $\begin{array}{l}\text { Storage array for vertical coordinates of } \\
\text { isotherm curves for later plotting }\end{array}$ \\
\hline ARRAYX & (50) & & $\begin{array}{l}\text { Storage array for horizontal coordinates of } \\
\text { outl ine of body of water }\end{array}$ \\
\hline ARRAYY & $(50)$ & & $\begin{array}{l}\text { Storage array for vertical coordinates of } \\
\text { outline of body of water }\end{array}$ \\
\hline L & & & $\begin{array}{l}\text { Random number chosen from uniform distribution } \\
\text { on the interval }(0,1)\end{array}$ \\
\hline DDIFF & & & $\begin{array}{l}\text { Difference between the dissolved oxygen level } \\
\text { at the current position of the fish and its } \\
\text { minimum tolerable dissolved oxygen level }\end{array}$ \\
\hline DDIFFA & & & $\begin{array}{l}\text { Difference between dissolved oxygen level of } \\
\text { any of the next eight possible positions of } \\
\text { the fish and its minimum tolerable dissolved } \\
\text { oxygen level }\end{array}$ \\
\hline DDR & $(3,3)$ & $I(k, m)$ & $\begin{array}{l}\text { Measure of the strength of the inertia of } \\
\text { forward movement of the fish }\end{array}$ \\
\hline DIR & $(3,3)$ & $\mathrm{DO}(k, \mathrm{~m})$ & $\begin{array}{l}\text { Attraction of point }(k, m) \text { on fish because of } \\
\text { the difference in the dissolved oxygen level } \\
\text { from that of the current location of the fish }\end{array}$ \\
\hline DISOX & $(100)$ & DISOX $(k, m)$ & $\begin{array}{l}\text { Storage array for dissolved oxygen levels } \\
\text { along some given horizontal line, } k\end{array}$ \\
\hline DOX & & $\operatorname{DISOX}(i, j)$ & $\begin{array}{l}\text { Level of dissolved osygen at the current } \\
\text { position of the fish }\end{array}$ \\
\hline
\end{tabular}


Table 1. (continued)

\begin{tabular}{|c|c|c|c|}
\hline $\begin{array}{l}\text { Fortran } \\
\text { variable } \\
\text { name }\end{array}$ & $\begin{array}{l}\text { Dimension } \\
\text { (if array) }\end{array}$ & $\begin{array}{l}\text { Ma thematical } \\
\text { s:mbol }\end{array}$ & Definitior. \\
\hline DOXFOR & & ${ }^{5} \mathrm{DO}$ & $\begin{array}{l}\text { Attractive force of higher dissolved oxygen } \\
\text { level on fish movements. }\end{array}$ \\
\hline DOXMIN & & DISax $_{\min }$ & $\begin{array}{l}\text { Minimum tolerable dissolved oxygen level } \\
\text { for fish }\end{array}$ \\
\hline EPTIA & $(5)$ & $e_{i}$ & Strength of forward inertia of fish \\
\hline FUALP & $(20)$ & ${ }^{-x} \mathrm{Fo}$ & $\begin{array}{l}\text { Parameter describing the spatial distribution } \\
\text { of food about each of the centers of food } \\
\text { availability (see Eq. 24) }\end{array}$ \\
\hline F[ATCT & & ${ }^{5} F, q$ & $\begin{array}{l}\text { Force of attraction of food availability on } \\
\text { fish movements }\end{array}$ \\
\hline FOBET & $(20$, & ${ }^{3} \mathrm{Fq}$ & $\begin{array}{l}\text { Parameter describing the spatial distribution } \\
\text { of food about each of the centers of food } \\
\text { availabiliti (see Eq. 24) }\end{array}$ \\
\hline FDIQ & $(20$ & $\mathbf{I}_{\mathrm{Fq}}$ & $\begin{array}{l}\text { Parameter (horizontai coordinate) describing } \\
\text { the spatial distribution of food about each } \\
\text { of the centers of food avai ability (see Eq. 24) }\end{array}$ \\
\hline FDJU & $(20 ;$ & $\mathrm{d}_{\mathrm{Fq}}$ & Same as above definition (vertical coordinate) \\
\hline FDNUM & $(20)$ & $\mathbf{F}_{0}$ & $\begin{array}{l}\text { Parameter describing the spetial distribution } \\
\text { of favorable habitat about each of the centers } \\
\text { of food availability (see Ec. 24) }\end{array}$ \\
\hline FDR & $(3,3)$ & $F_{Q}(k, \pi)$ & $\begin{array}{l}\text { Attraction of point }(k, m) \text { or fish because of the } \\
\text { difference in food availability from the current } \\
\text { location }(i, j)\end{array}$ \\
\hline F00D & & & $\begin{array}{l}\text { Measure of the amount of focd available to the } \\
\text { fish at its current location }\end{array}$ \\
\hline FOODA & & & $\begin{array}{l}\text { Measure of the amount of food available to fish } \\
\text { in its possible next locatian }\end{array}$ \\
\hline
\end{tabular}


Table 1. (continued)

\begin{tabular}{|c|c|c|c|}
\hline $\begin{array}{l}\text { Fortran } \\
\text { variable } \\
\text { name }\end{array}$ & $\begin{array}{l}\text { Dimension } \\
\text { (if array) }\end{array}$ & $\begin{array}{l}\text { Ma thematical } \\
\text { symbol }\end{array}$ & Definition \\
\hline GRID & $(90,60)$ & & $\begin{array}{l}\text { Array that stores information on the type of } \\
\text { region each grid point is in, as well as its } \\
\text { temperature and dissolved oxygen level }\end{array}$ \\
\hline HAB & & & $\begin{array}{l}\text { Measure of the favorability of habitat at the } \\
\text { current location of the fish }\end{array}$ \\
\hline HABA & & & $\begin{array}{l}\text { Measure of the favorability of habitat at the } \\
\text { possible next location of the fish }\end{array}$ \\
\hline HABALP & $(20)$ & $\alpha_{\mathrm{Hq}}$ & $\begin{array}{l}\text { Parameter describing the spatial distribution } \\
\text { of favorable habitat about each of the centers } \\
\text { of favorable habitat (in equation analogous } \\
\text { to Eq. } 24 \text { ) }\end{array}$ \\
\hline HBATCT & & $\mathrm{s}_{\mathrm{H}, \mathrm{q}}$ & $\begin{array}{l}\text { Force of attraction of habit favorability on } \\
\text { fish movements }\end{array}$ \\
\hline HBBET & $(20)$ & $B_{H, q}$ & $\begin{array}{l}\text { Parameters describing the spatial distribution } \\
\text { of favorable habitat about each of the centers } \\
\text { of favorable habitat (in equation analogous } \\
\text { to Eq. 24) }\end{array}$ \\
\hline HBIQ & $(20)$ & $\mathrm{I}_{\mathrm{H}, \mathrm{q}}$ & $\begin{array}{l}\text { Center of a region of favorable habitat } \\
\text { (horizontal coordinate) }\end{array}$ \\
\hline HBJQ & $(20)$ & $\mathrm{J}_{H, q}$ & $\begin{array}{l}\text { Center of a region of favorable habitat } \\
\text { (vertical coordinate) }\end{array}$ \\
\hline HBNUM & $(20)$ & $H_{D}$ & $\begin{array}{l}\text { Parameters describing the spatial distribution } \\
\text { of favorable habitat about each of the centers } \\
\text { of favorable habitat (in equation analogous to } \\
\text { Eq. 24) }\end{array}$ \\
\hline IDISOX & & & $\begin{array}{l}\text { Logical variable specifying whether dissolved } \\
\text { oxygen levels are described by a mathematical } \\
\text { function (IDISOX=0) or point by point } \\
\text { (IDISOX=1) }\end{array}$ \\
\hline
\end{tabular}


Table 1. (con-inued)

\begin{tabular}{ccc}
\hline $\begin{array}{c}\text { Fortran } \\
\text { variable } \\
\text { name }\end{array}$ & $\begin{array}{c}\text { Dimension } \\
\text { (if array): }\end{array}$ & $\begin{array}{c}\text { Mathematical } \\
\text { symbol }\end{array}$ \\
\hline
\end{tabular}

IPLOT

IPRES

ISDTH

ISTRT

ITEM

IX

JPRES

JSTRT

MDIST

NFISH

NFOOD

NHAB

NHOR

NREG

NSV
Logical variable specifying whether or not fish paths are to be plotted

Current position of the fis (norizontal coordinate)

Logical variable specifying whether or not the isotherms are to be plottes

Horizontal coordinate of the starting position of a given fish

Logical variable specifying whether temperature is described by a mathematical function (ITEM=0) or by point-by-point data ( -TEM=1)

Pseudo-random number generazor initiator

Current position of the $=i$ hh (vertical coordinate)

Starting position of the fish (vertical coordinate)

Integer variable that increcses by 1 for each step a particular fish takes. When NDIST=NSTEPS, no further steps are taken

Number of fish simulated in the body of water Number of centers of food atailability

Number of centers of high habitat favorability Number of horizontal grid ines

Number of environmental regions [usually there will be only two; (1) the bcdy of water, and (2) the surrounding air ind land]

Integer variable that increases by 1 for each fish that is "inserted" "riac the body of water. When NSV = NFISH, no further fish are inserted. 
Table 1. (continued)

\begin{tabular}{|c|c|c|c|}
\hline $\begin{array}{l}\text { Fortran } \\
\text { variatle } \\
\text { name }\end{array}$ & $\begin{array}{l}\text { Dimension } \\
\text { (if array) }\end{array}$ & $\begin{array}{c}\text { Ma thematical } \\
\text { symbol }\end{array}$ & Definition \\
\hline NSTEPS & & & $\begin{array}{l}\text { Number of steps in space that each fish is } \\
\text { allowed to take }\end{array}$ \\
\hline NVER & & & Number of vertical grid lines \\
\hline RES & $(50)$ & $B(k, m)$ & $\begin{array}{l}\text { Boundary crossing factors (causing fish to } \\
\text { remain in the body of water) }\end{array}$ \\
\hline SAVI & $(500)$ & $\cdot$ & $\begin{array}{l}\text { Array that stores horizontal coordinates of } \\
\text { fish movement for later plotting }\end{array}$ \\
\hline SAVJ & $(500)$ & . & $\begin{array}{l}\text { Array that stores vertical coordinates of } \\
\text { fish movement for later plotting }\end{array}$ \\
\hline TDIFF & & $d_{T}(i, j)$ & $\begin{array}{l}\text { Difference between temperature of current } \\
\text { position of fish and its preferred temperature }\end{array}$ \\
\hline TDIFFA & & $d_{T}(k, m)$ & $\begin{array}{l}\text { Difference between temperature of possible } \\
\text { next position of the fish and its preferred } \\
\text { temperature }\end{array}$ \\
\hline TDR & $(3,3)$ & $T_{q}(k, m)$ & $\begin{array}{l}\text { Attraction of point }(k, m) \text { on the fish because } \\
\text { of the difference on temperature from its } \\
\text { current position }\end{array}$ \\
\hline TEMH & & & Temperature of maximum isotherm to be plotted \\
\hline TEMINT & & & Width of intervals between isotherms \\
\hline TEML & & & Temperature of minimum isotherm to be plotted \\
\hline TEMFOR & & $\mathrm{s}_{\mathrm{T}}$ & $\begin{array}{l}\text { Force of attraction of preferred temperature } \\
\text { of fish }\end{array}$ \\
\hline TEMP & & & Temperature at current location of fish \\
\hline TEMPA & $(100)$ & $\operatorname{TEMP}(i, j)$ & $\begin{array}{l}\text { Storage array for temperature data along a } \\
\text { given horizontal line, } i\end{array}$ \\
\hline TEMPRF & & TEMP $_{p}$ & Preferred temperature of the fish \\
\hline v & $(3,3)$ & $p_{i j, k m}$ & $\begin{array}{l}\text { Transition probability from grid point }(i, j) \\
\text { to grid point }(k, m)\end{array}$ \\
\hline
\end{tabular}


Table 2. Parameter values for the example in Fig. 5

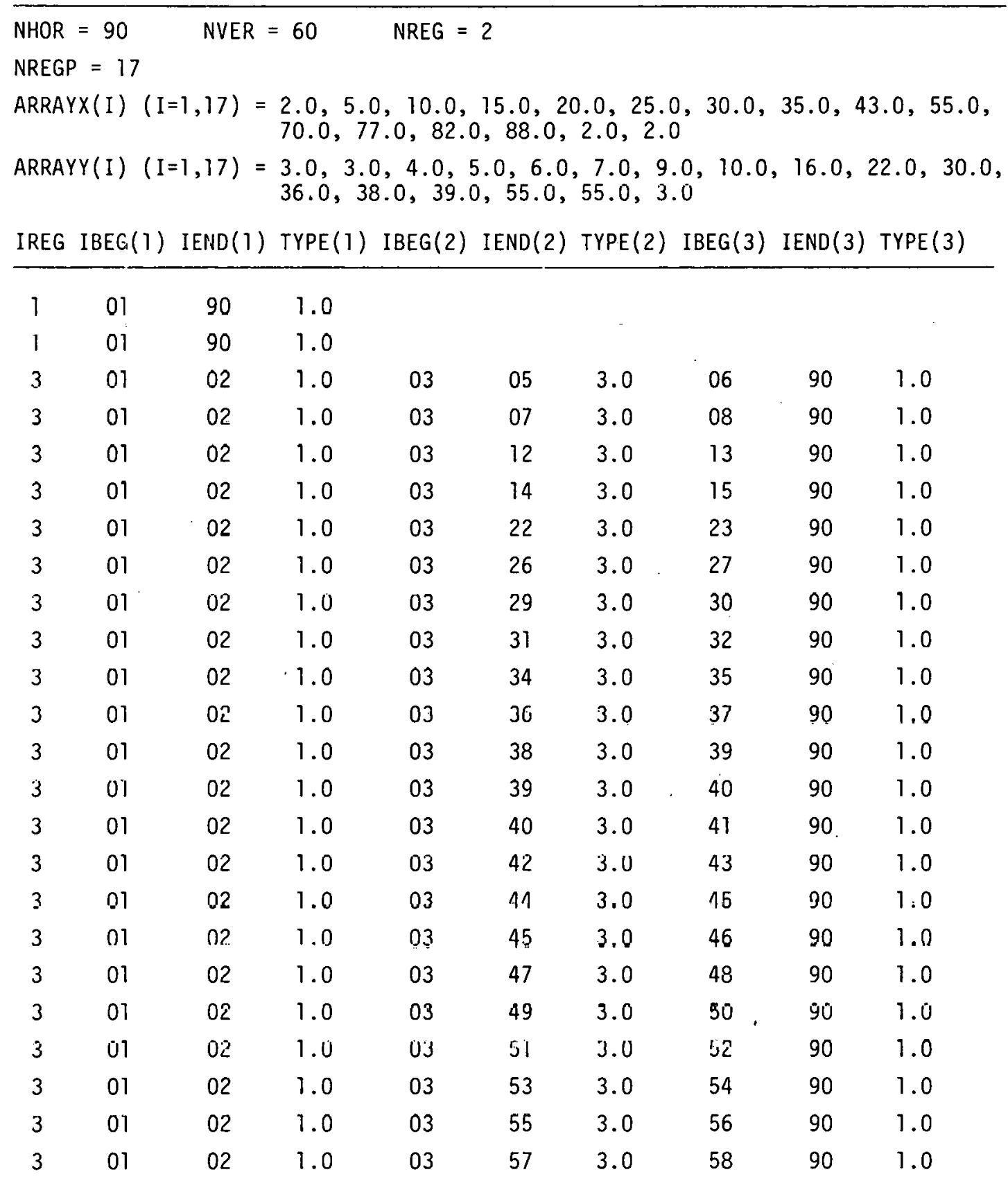


Table 2. (continued)

\begin{tabular}{|c|c|c|c|c|c|c|c|c|c|}
\hline IREG & $\operatorname{IBEG}(1)$ & $\operatorname{IEND}(1)$ & TYPE(1) & $\operatorname{IBEG}(2)$ & $\operatorname{IEND}(2)$ & TYPE (2) & $\operatorname{IBEG}(3)$ & $\operatorname{IEND}(3)$ & TYPE (3) \\
\hline 3 & 01 & 02 & 1.0 & 03 & 59 & 3.0 & 60 & 90 & 1.0 \\
\hline 3 & 01 & 02 & 1.0 & 03 & 61 & 3.0 & .62 & 90 & 1.0 \\
\hline 3 & 01 & 02 & 1.0 & 03 & 63 & 3.0 & 64 & 90 & 1.0 \\
\hline 3 & 01 & 02 & 1.0 & 03 & 65 & 3.0 & 66 & 90 & 1.0 \\
\hline 3 & 01 & 02 & 1.0 & 03 & 66 & 3.0 & 67 & 90 & 1.0 \\
\hline 3 & 01 & 02 & 1.0 & 03 & 68 & 3.0 & 69 & 90 & 1.0 \\
\hline 3 & 01 & 02 & 1.0 & 03 & 69 & 3.0 & 70 & 90 & 1.0 \\
\hline 3 & 01 & 02 & 1.0 & 03 & 71 & 3.0 & 72 & 90 & 1.0 \\
\hline 3 & 01 & 02 & 1.0 & 03. & 72 & 3.0 & 73 & 90 & 1.0 \\
\hline 3 & 01. & 02 & 1.0 & 03 & 73 & 3.0 & 74 & 90 & 1.0 \\
\hline 3 & 01 & 02 & 1.0 & 03 & 74 & 3.0 & 75 & 90 & 1.0 \\
\hline 3 & 01 & 02 & 1.0 & 03 & 75 & 3.0 & 76 & 90 & 1.0 \\
\hline 3 & 01 & 02 & 1.0 & 03 & 76 & 3.0 & 77 & 90 & 1.0 \\
\hline 3 & 01 & 02 & 1.0 & 03 & 80 & 3.0 & 81 & 90 & 1.0 \\
\hline 3 & 01 & 02 & 1.0 & 03 & 87 & 3.0 & 88 & 90 & 1.0 \\
\hline 3 & 01 & 02 & 1.0 & 03 & 87 & 3.0 & 88 & 90 & 1.0 \\
\hline 3 & 01 & 02 & 1.0 & 03 & 87 & 3.0 & 88 & 90 & 1.0 \\
\hline 3 & 01 & 02 & 1.0 & 03 & 87 & 3.0 & 88 & 90 & 1.0 \\
\hline 3 & 01 & 02 & 1.0 & 03 & 87 & 3.0 & 88 & 90 & 1.0 \\
\hline 3 & 01 & 02 & 1.0 & 03 & 87 & 3.0 & 88 & 90 & 1.0 \\
\hline 3 & 01 & 02 & 1.0 & 03 & 87 & 3.0 & 88 & 90 & 1.0 \\
\hline 3 & 01 & 02 & 1.0 & 03 & 87 & $3.0^{\circ}$ & 88 & 90 & 1.0 \\
\hline 3 & 01 & 02 & 1.0 & 03 & 87 & 3.0 & 88 & 90 & 1.0 \\
\hline 3 & 01 & 02 & 1.0 & 02 & 87 & 3.0 & 88 & 90 & 1.0 \\
\hline 3 & 01 & 02 & 1.0 & 03 & 87 & 3.0 & 88 & 90 & 1.0 \\
\hline 3 & 01 & 02 & 1.0 & 03 & 87 & 3.0 & 88 & 90. & 1.0 \\
\hline 3 & 01 & 02 & 1.0 & 03 & 87 & 3.0 & 88 & 90 & 1.0 \\
\hline 3 & 01 & 02 & 1.0 & 03 & 87 & 3.0 & 88 & 90 & 1.0 \\
\hline 3 & 01 & 02 & 1.0 & 03 & 87 & 3.0 & 88 & 90 & 1.0 \\
\hline 3 & 01 & 02 & 1.0 & 03 & 87 & 3.0 & 88 & 90 & 1.0 \\
\hline 3 & 01 & 02 & 1.0 & 03 & 87 & 3.0 & 88 & 90 & 1.0 \\
\hline 1 & 01 & 90 & 1.0 & & & & & & \\
\hline 1 & 01 & 90 & 1.0 & & & & & & \\
\hline 1 & 01 & 90 & 1.0 & & & & & & \\
\hline 1 & 01 & 90 & 1.0 & & & & & & \\
\hline 1 & 01 & 90 & 1.0 & & & & & & \\
\hline
\end{tabular}


Table 2. (continued)




to the preferred temperature. The distribution of fish after 200 steps is shown in Fig. 8, for parameter values given in Table 2, except that now NFISH $=500$ and IPLOT $=0$. It is interesting to look at the histogram describing the percent distribution of fish about the preferred temperature of $29.0^{\circ} \mathrm{C}$ (Fig. 9), since this can be compared with laboratory data, such as that shown in Fig. 10 for largemouth bass (Reynolds and Casterlin 1975). The agreement is not bad (although the model results are more peaked and lack the skewing seen in the experiment), which is some indication that we have chosen a reasonable set of parameters for our mode 1; however, other choices of parameter values may give better results.

Next we add in the effects of dissolved oxygen (Fig. 1), food availability (Fig. 4), and habitat preferenda, with the appropriate changes in parameter values from Table 2 shown in Table 3. The ultimate average distribution of fish is now greatly altered (Fig. 11).

\section{DISCUSSION AND SUMMARY}

The model described in this report is designed to simulate the movements of individual fish in a body of water and to predict the spatial patterns of a population of $f$ ish under the influence of temperature, dissolved oxygen levels, food availability and habitat preferences. The body of water is represented by a two-dimensional grid of points, with water depth and longitudinal axis being the coordinates. The simulated fish takes one spatial step at a time, the direction of travel being chosen by a pseudo-random number generator, but biased by the initial direction of motion of the fish, as well as its response to temperature gradients and the other factors mentioned above. Model output is plotted in graphs.

This model is designed for use in planning and evaluating the results of experimental laboratory and field studies of fish movement and spatial distribution. The application of the model to experimental data is still in a preliminary stage, and the development of the model into an effective predictive tool will take continued work. The model 




Fig. 9. Histogram of percent distribution of fish in Fig. 8 about the preferred temperature of $29.0^{\circ} \mathrm{C}$. 




Fig. 10. Histogram of relative frequency of largemouth bass in ambient water temperatures during daytime (from Reynolds and Casterlin 1977). 
FISH DISTRIBUTION

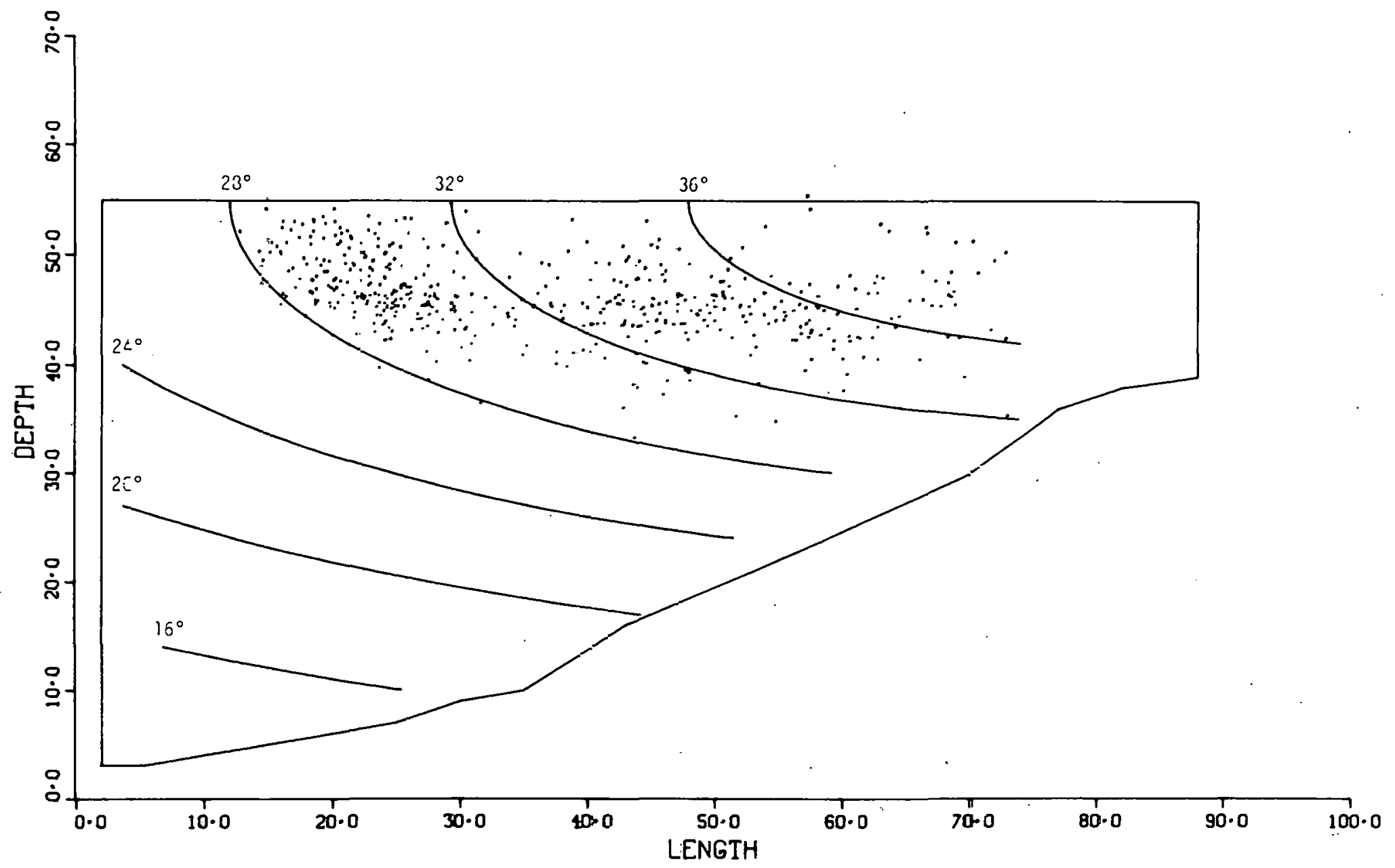

Fig. 11. The distribution of 500 fish influenced by temperature, dissolved oxygen, food availability and habitat favorability in the reservoir after 200 steps. Parameter values are given in Table 3. 
Table 3. Changes in paremeter values from Table 2. relevant to the case shown in Fig. 11

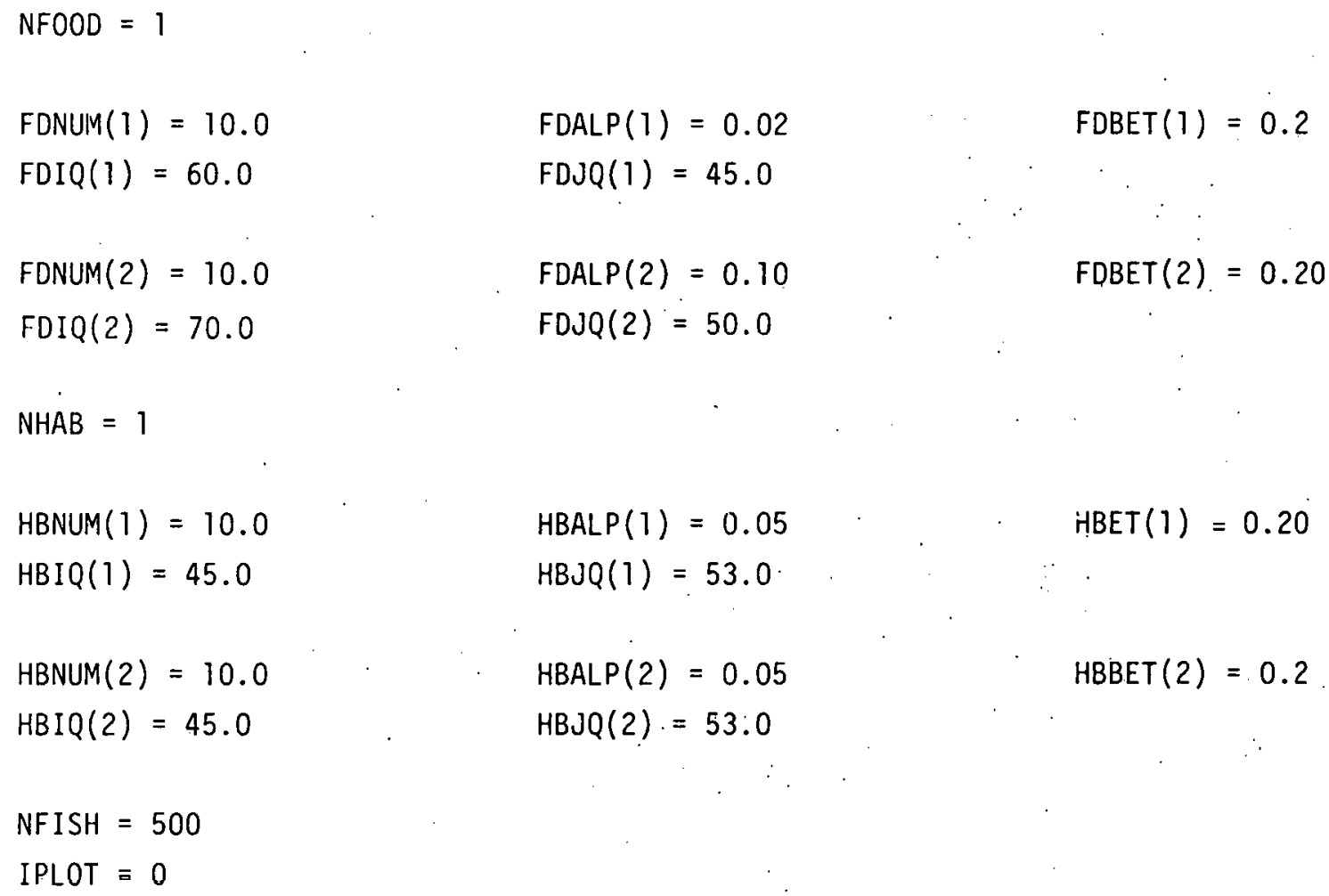


is flexible enough to take into account most of the important factors influencing fish movement, but considerable effort needs to be expended in quantifying these factors. 


\section{REFERENCES}

Coutant, C. C. 1975. Responses of bass to natural and artificial temperature regimes. pp. 272-285. IN: Stroud, R. H., and $H$. Clepper (eds.), Black Bass Biology and Management. Sports Fishing Institute, Washington, DC. $534 \mathrm{pp}$.

Coutant, C. C., and D. K. Cox. 1976. Growth rates of subadult largemouth bass at 24 to 35.5 C. pp. 188-120. IN: Esch, G. W., and R. W. McFarlane (eds.), Thermal Ecology II. ERDA Symposium Series CONF-750425.' National Technical Information System, Springfield, VA.

Fraenkel, G. S., and D. L. Gunn. 1961. The Orientation of Animals (revised edition). Dover Pub., Inc., New York. 376 pp.

Gibbons, J. W., J. T. Hook, and D. L. Forney. 1972. Winter responses of 1 argemouth bass to heated effluent from a nuclear reactor. Prog. Fish Cult. 34(2):88-90.

Kitchell, J. F., J. F. Koonce, R. V. O'Neill, H. H. Shugart, Jr., J. J. Magnuson, and R. S. Booth. 1974. Model of fish biomass energetics. Trans. Am. Fish. Soc. 103(4):786-798.

McCauley;, R., and N. Huggins. 1976. Behavioral thermoregulation by rainbow trout in a temperature gradient. pp. 171-175. IN: Esch, G. W., and R. W. McFarlane (eds.), Thermal Ecology II. ERDA Symposium Series CONF-750425. National Technical Information System, Springfield, VA.

McGarth, E. J., and D. C. Irving. 1975. Techniques for efficient Monte Carlo simulation. Vol. II. Random number generation for selected probability distributions. ORNL/RSIC-38 (Vol. 2). Oak Ridge National Laboratory, Oak Ridge, TN.

Moss, D. D., and D. C. Scott. 1961. Dissolved oxygen requirements of three species of fish. Trans. Am. Fish. Soc. 90(4);377-393. Neill, W. H. 1976. Mechan isms of behavioral thermoregulation in fishes. pp. 156-169. IN: Sigma Research Inc. (ed), Report of a Workshop on the Impact of Thermal Power Plant Cooling Systems on Aquatic. Environments. Electric Power Research Institute, Palo Alto, CA. 
Peterson, S. E., and R. M. Schutsky. 1976. Some relationships of upper thermal tolerances to preference and avoidance responses of the bluegill. pp. 148-153. IN: Esch, G. W., and R. W. McF arlane (eds.), Thermal Ecology II. ERDA Symposium Series CONF-750425. National Technical Information System, Springfield, VA.

Reynolds, W. W., and M. E. Casterlin. 1976. Thermal preferenda and behavioral thermoregulation in three centrarchid fishes. IN: Esch, G. W., and R. W. McFar lane (eds.), Thermal Ecology II. ERDA Symposium Series CONF-750425. National Technical Information System, Springfield, VA.

Smith, S. F. 1972. Effects of a thermal effluent on aquatic life in an Cast Tennesset reservo1r. Proc. 25th Annu. Conf. S. E. Game and Fish Comm., 374-384.

Stuntz, W. E., and J. J. Magnuson. 1976. Daily ration, temperature selection, and activity of bluegill. pp. 180-184. IN: Esch, G. W., and R. W. McFarlane (eds.), Thermal Ecology II. ERDA Symposium Series CONF-750425. National Technical Information System, Springfield, VA.

Warden, R. L., Jr., and W. J. Lorio. 1975. Movements of largemouth bass (Micropterus salmoides) in impounded waters as determined by underwater to lemetry. Trans. Am. rish. Söc. 104(4):696-702. 
APPENDIX: THE COMPUTER PROGRAM 
THIS PAGE

\section{WAS INTENTIONALLY LEFT BLANK}


0001






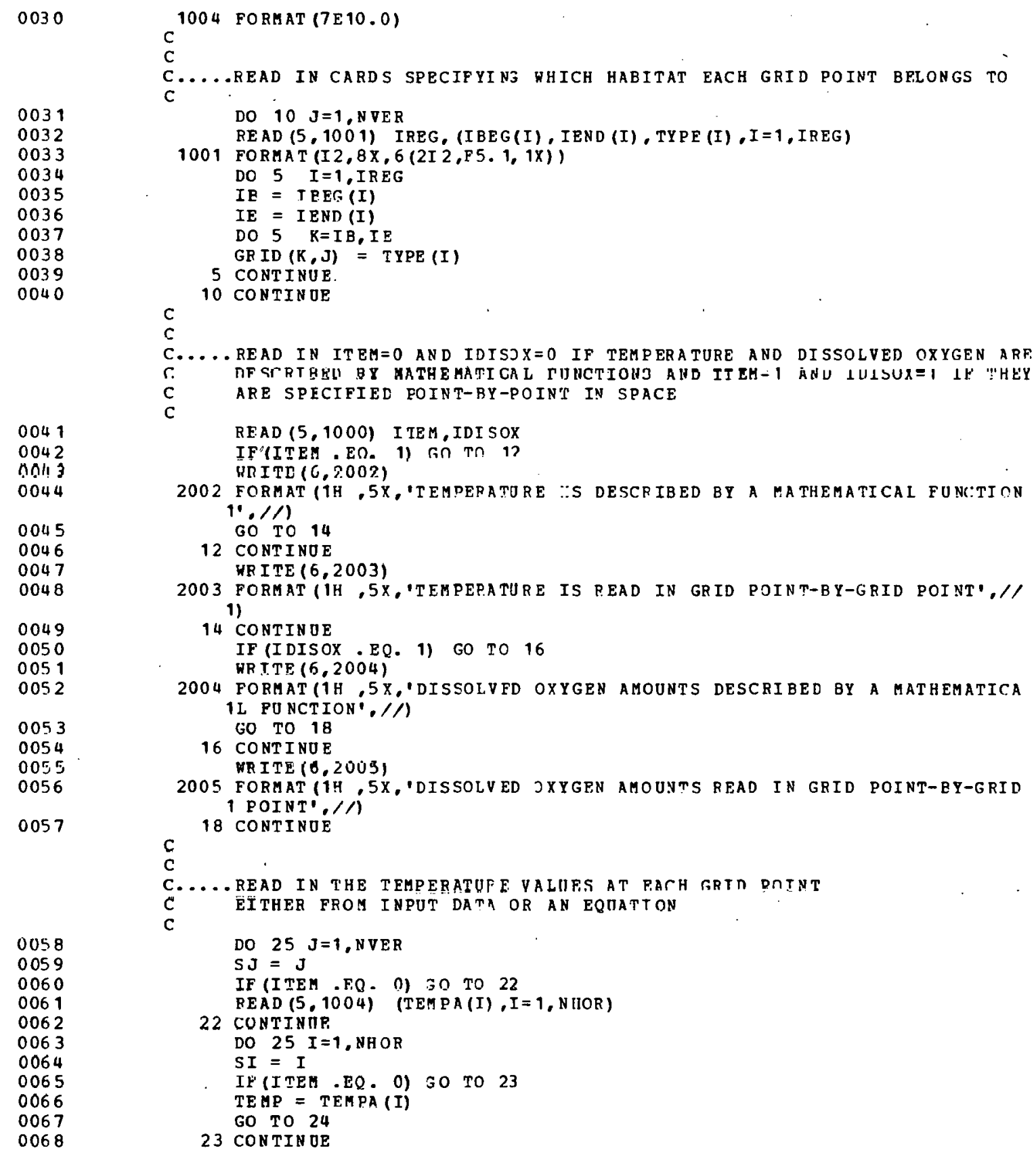




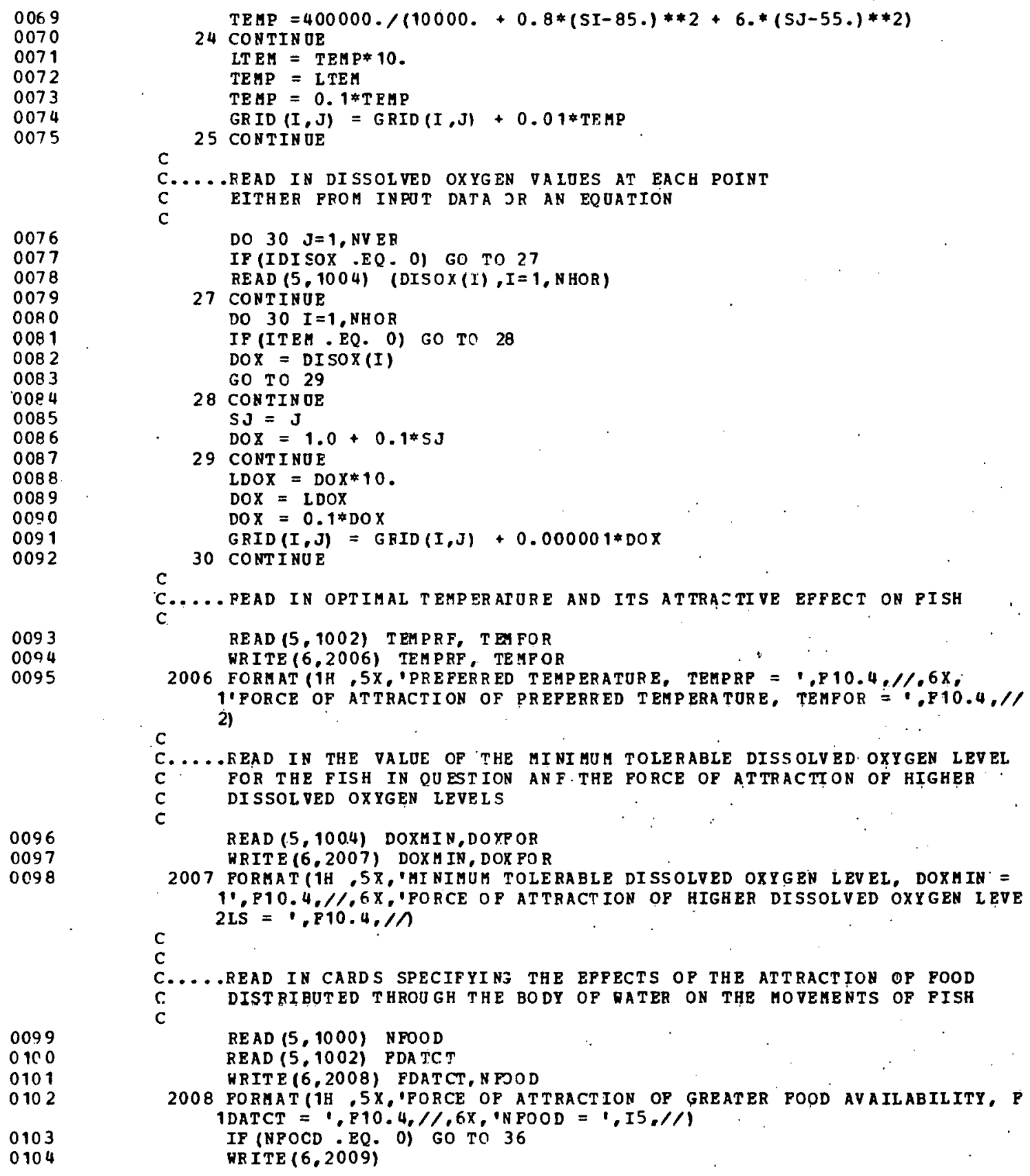


0105

0106

0107

0108

0109

0110

0111

0112

0113

0114

0115

0116

0117

0118

0119

0120

0121

0122

0123

0124

0125

0126

0127

0128

0129

0130

0131

0132

0133

0134

0135

0136

0137

0138

2009 FORMAT (1H $, 12 \mathrm{X},{ }^{\prime}$ FOOD D ISTR IBOTION COEFPICIENTS' $/ .6 \mathrm{X}$, 'PDNUH $^{\prime}, 12 \mathrm{X}$, 1'FDALP', 12X,'PDBET', $12 \mathrm{X}$, 'PDIQ', 13X,'PDJQ', 1

DO $35 I=1$, N FOOD

$\operatorname{READ}(5,1002)$ FDNUM (I), FDALP (I), FDBET(I), FDIQ (I), FDJQ (I)

WR ITE $(6,2010)$ FDNUM (I), FDALP(I), FDBET(I),FDIQ (I), PDJQ (I)

2010 FORMAT $(1 \mathrm{H}, 5 \times, 6(\mathrm{E} 15.8,2 \mathrm{X}))$

35 CONTINOE

C

36 CONTIN OE

C.....READ IN CARDS SPECIFYINB THE EFFECTS OF THE ATTRACTION OF HABITATS

C IN THE BODY OF WATER ON THE MOVEHENTS OF FISH

2020 WRITE $(6,2020)$

READ $(5,1000)$ NHAB

READ $(5,1002)$ HBATCT

WRITE $(6,2012)$ HBATCT, N HA B

2012 FORHAT $1 \mathrm{H}, 5 \mathrm{X}$, 'FORCE OF ATTRACTION OF HABTTAT PREFERENCES, HBATCT

$1=1, \mathrm{P} 10.4,1 /, 6 \mathrm{X}, \mathrm{NHAB}=1, \mathrm{I} 5,1 / 1$

IF (NHAB. EO. O) GO TO 41

WR TTE. $(6,2011)$

2011 FORMAT (1H, $12 X^{\prime}$ 'HABITAT DIST: IBUTION COEFFIZIENTS', /,6X, 'HBNOH',

$112 \mathrm{X}$, 'HBALP', $12 \mathrm{X}$, 'HBBET', $12 \mathrm{X}$, 'HBIQ',13X,'HBJQ', /) ,

In $40 \mathrm{~T}=1$. N HAB

READ (5, 1002) HBNUM(I), HBALP (I), HBBET(I), HBIO (I), HBJO(I)

WRITF $(6,2010)$ HBNIM (I) , HBAIP (I), HBBET(I), HBIQ (I) , HBJQ (I)

40 CONTINUE

41 CONTINUE

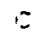

..... READ IN BOUNDARY CROSSING FACTOKS FOR KEEPING FISH IN THE BODY OF WATER $\operatorname{READ}(5,1002) \quad(\operatorname{RES}(I), I=1, N R E G)$

1002 FORMAT (JE 10.0)

VRITE $(6,2020)$

URITE $(6,2013)$ (RES (I), I=1,NREG)

2013 FORMAT $(1 \mathrm{H}, 5 \mathrm{X}$, BOUNDARY CROSSING FACTORS, RES(I) $=., 4(\mathrm{P} 9.3 .2 \times) .1 /$ 1)

HITE $(6,2020)$

is

$c$

C....READ IN THE 'INERTIA' VATIP, OR TENDENCY TO CONTINUE MOVING IN SAME DI RECTIOH

READ (5, 1002) (ERT IA (I) , I=1,5)

WRITE $(6,2014)$ (ERTIA (I), I = 1,5)

2014 PORHAT (1H, $5 \mathrm{X}$, VAALES OP FORWARD INERTIA, ERTIA $=1.5(\mathrm{~F} 6.2,1 \mathrm{X}), 1 /)$

C

C

C.... PEAD IN RANDOM NUMBER GENERATOR TNTTTALIZATION

C HHE INITITATES SUBROOTINE RANSET AND SHOULD BE LEFT AT THE VALUE BELOH

$\operatorname{READ}(5,1000) \quad \mathrm{IX}$

WRITE $(6,2015)$ IX

2015 PORMAT (1H, 5X, 'RANDOM NOMBER INITIATOR, IX $=1, \mathrm{I} 5, / 1$

MM $=2147483647$ 
0139

0140

0141

0142

0143

0144

0145

0146

0147

0148

0149

0150

0151

0152

0153

0154

01.55

0156

0157

0158

0159

0150

0161

0162

0163

0164

0165

0166

0167

0168

C
C
C
C
C
C

CALL RANSET (MH, IX)

C.... READ IN THE NUMBER OF OF FISH IN THE BODY OF WATER AND THE NUABER

C OF STEPS EACH TAKES

READ $(5,1000)$ NPISH, NSTEPS HRIT E $(6,2016)$ NPISH, NSI EPS


$16 X$, NUMBE OF STEPS EACH PISH IS ALLONED TO TAKE,. NSTEPS $=$ T IS, $2 / 11$

C

C

C.....READ IN IPLOT=1 IF FISH PATHS APE TO BE PLOTTED, IPLOT=O OTHEREISE

C

C

C.... READ IN ISOTH=1 IF ISOTHERMS ARE TO BE PLOTTED, ISOTH=0 OTHERRISE

C

READ $(5,1000)$ IPLOT, ISOTH

IF (IPLOT . NE . 1) GO TO 45

WTTE $(6,2017)$

2017 PORHAT $(1 \mathrm{H}, 5 \mathrm{X}$, 'PISH PATHS ARE PLOTTED', $/ 1$

45 CONTINOE

IF (ISOTH . NE . 1) GO TO 47

HRITE $(6,2018)$

2018 FORMAT (1H .58, 'ISOTHERMS ARE PLOTTED', $/ 1$

$\mathrm{C}$

47 CONTINOE

C.... READ IN THE MINIROM AND MAXIMUH ISOTHERHS TO BE PLOTTED, AS MELL AS

C. THE TEHPERATURE INTERVALS BETHEEN THEM

IF (I SO TH . EO. O) GO TO 59

READ $(5,1004)$ TEHL, TEM H, I EH INT

WR ITE $(6,2019)$ TEML ,TEMH, TEMINT

2019 FORHAT (1H, 5X, "HINIMUM ISOTHERM PLOTTED, TEHL = $1.910 .4 .1 / .6 \mathrm{X}$

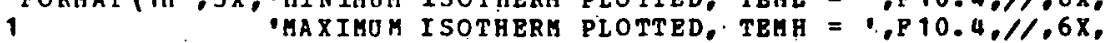

2 DISTANCE BETWEEN I SOTHERHS, TEHINT $=1$, P10.4, 11

59 CONTINUE

C

C

C

C.... ChOOSE AN INITIAL POSI TION AND SENSE OP DIBECTION OP TBE PISH RANDOMLI

60 CONTINDE

$I S V=1$

NDIST $=0$

SHOR = HHOR

SVER = NVER

65 CONTINOE

$D=$ ORAND (DUAY)

$D H=S$ HOR $* D$

$D=$ ORAND (DOMY)

$D V=S V R R D$

ISTRT $=\mathrm{DH}$ 


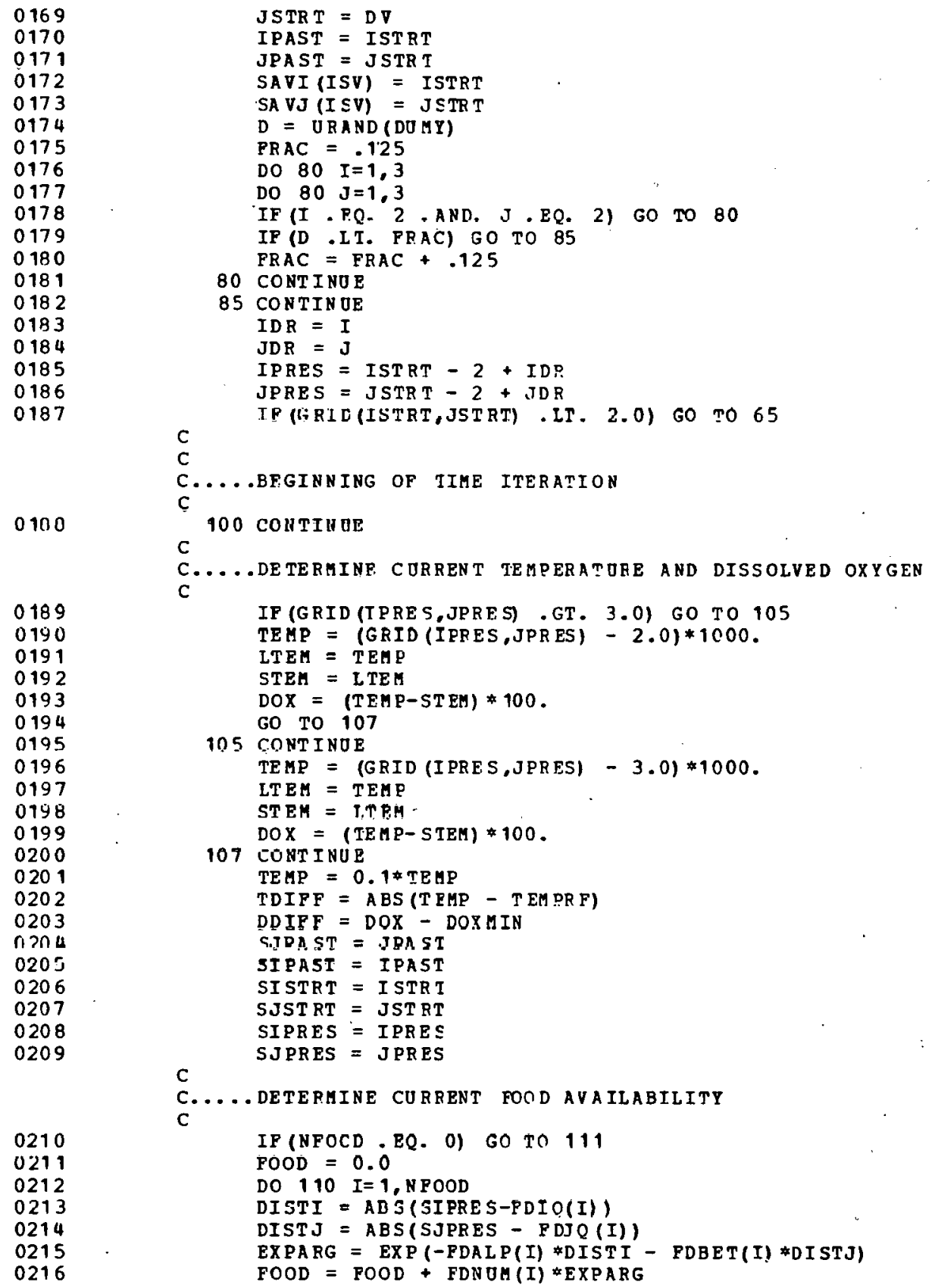




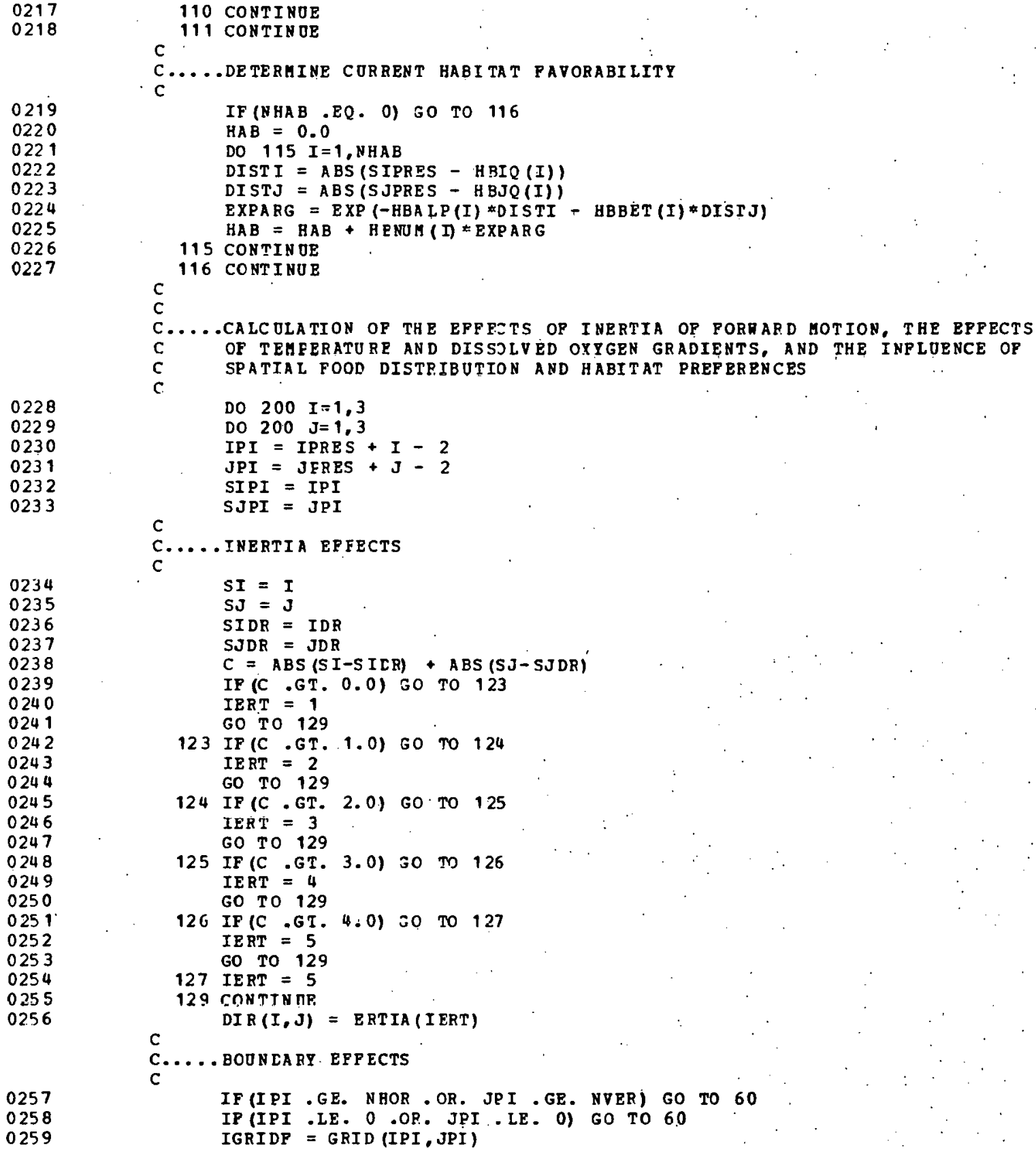


0260

026

0262

0263

0264

0265

0266

0267

0268

0269

0270

0271

0272

027

0274

0275

0276

0277

0278

0279

0280

0281

0282

0283

0284

0285

0286

0287

0288

O2R

0290

0291

ก.9

0293

0294

ก 20

0296

0297

0298

0299

0300

0301

0302

0303

0304

0305

0306

0307

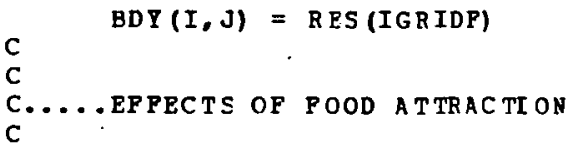

IF (N POOD .EQ. 0) GO TO 141

FOODA $=0.0$

DO $140 \quad R=1$, NFOOD

DISTI = ABS (SIPI - FDIO(K))

DISTJ $=$ ABS (SJPI - FDJQ(K) )

EXPARG = EXP (-FDALP(K) *DISTI - FDBET (K)*DISTJ)

FOODA $=$ FOODA + FDNOM $(K) \equiv$ EXPARG

140 CONTINOE

IF (POODA ILT. FOOD) GO TO 141

$\operatorname{FDR}(I, J)=$ FEATCT

GO TO 142

141 CONTINOE

$\operatorname{FDR}(I, J)=0.0$

C.... EFFECTS OP HAETTAT PREFFRENCF

IF (NHAR - EQ. 0) GO TO 151

$\mathrm{HABA}=0.0$

DO $150 \mathrm{~K}=1$, NHAB

DISTI = ABS (SIPI - HBI $Q(K))$

DISTJ = ABS (SJPI - HBJQ(K))

EXPARG = EXP (-HBALP $(K) \star D I S T I-H B B E T(K)$ \#DISTJ)

HABA $=$ HABA + HBNOM $(K)$ EXPARG

150 CONT INUE

IF (HABA. . T. HAB) GO TO 151

$\operatorname{HDR}(I, J)=$ HBATCT

GO TO 152

151 CONTINUE

$\operatorname{HDR}(I, J)=0.0$

C

152 CONTINOE

C.... TEMPERATURE AND DISSCLVED OXYGEN EFPECTS

$\operatorname{TDR}(I, J)=0.0$

IF (GRID (IPI. JPI) ,GT. 3. 月) GO TO 180

TEMP = (GRID (IPI, JPI) - 2.0)*1000.

LTEM = TEHE

$S T E M=I T E H$

DOX $=($ TEMP $-S T E M) * 100$.

6O du TUt

180 CONT INUE

TEMP $=($ GRID (IPI,JPI) - 3.0) $\$ 1000$.

LTEM $=$ TEMP

STEM = LTEH

DOX $=($ TE IY-STEH $) * 100$.

185 CONTINUE

TEHF $=0.1=$ 'I'EH

TDIFFA $=$ ABS (TEMP- TEM PRF)

DDIFPA $=$ DOX - DOXMIN

IF (TDIPFA .GT. TDIFF) GO TO 190

$\operatorname{TDR}(I, J)=T E M P O R$

GO TO 191 


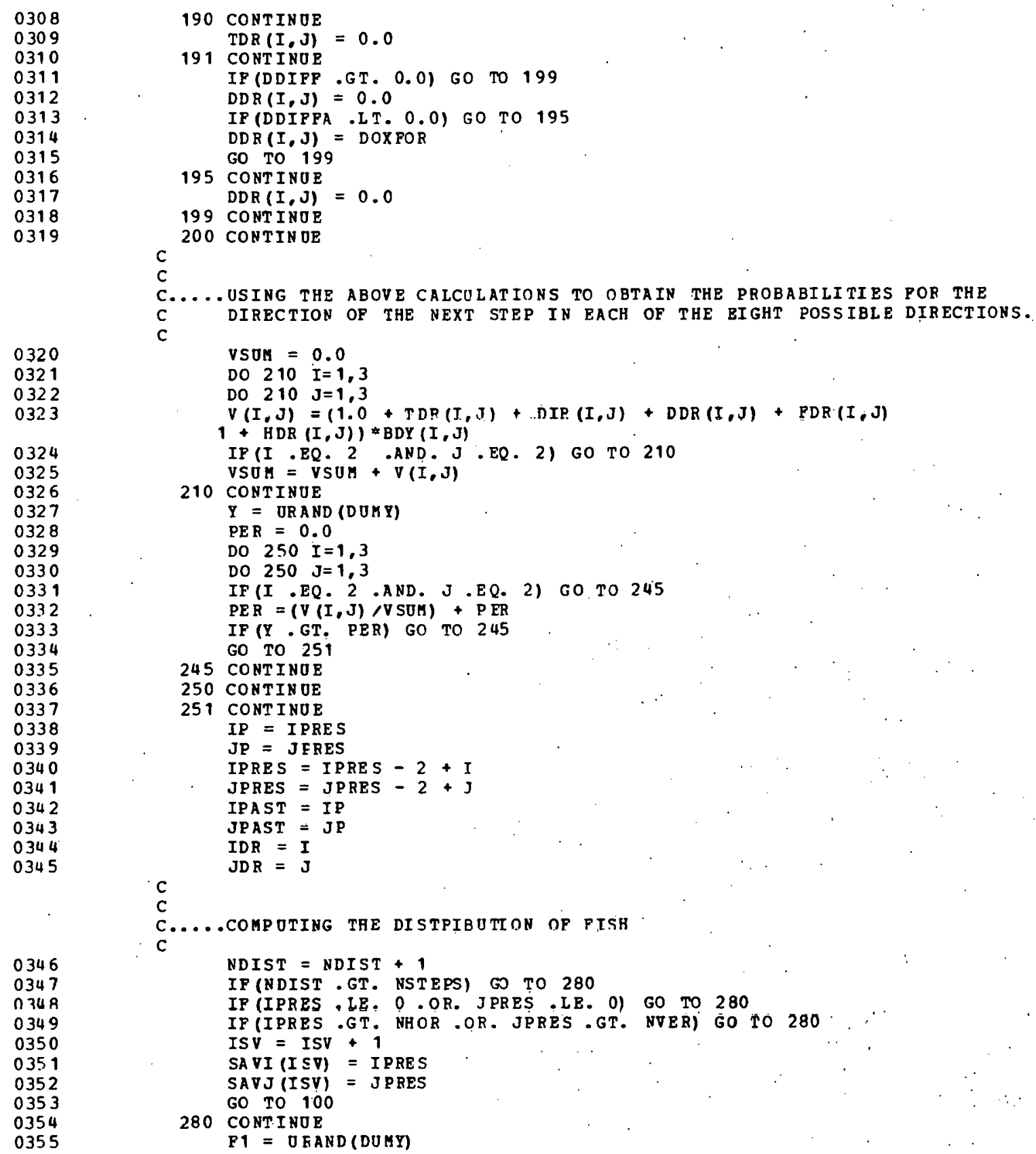




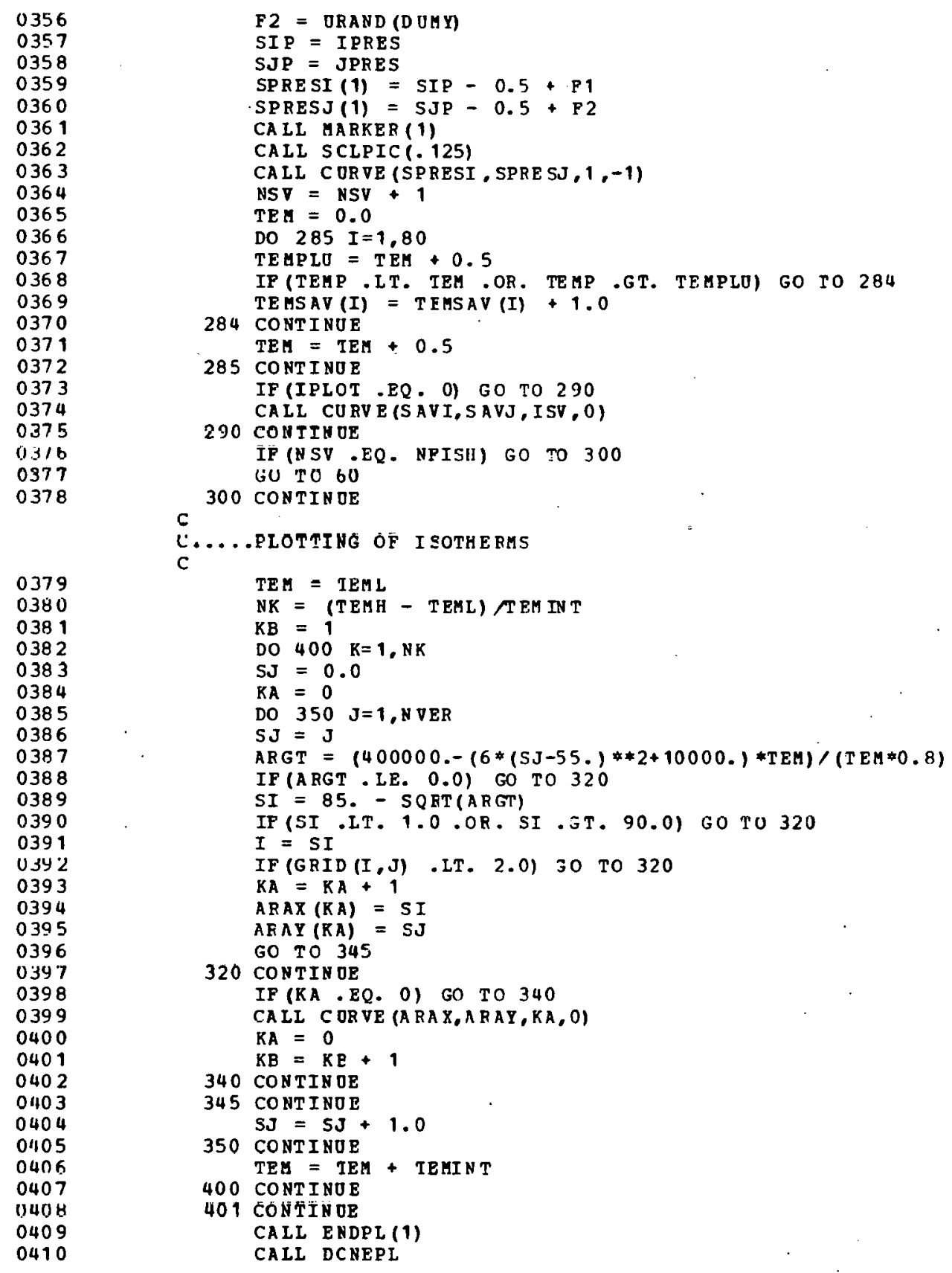




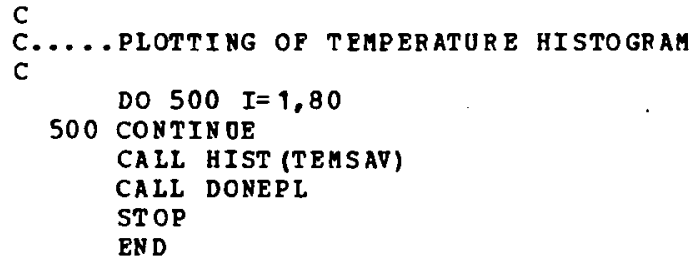












0001

0002

0003

0004

0005

0006

0007

0008

0009

0010

0011

0012

0013

0014

0015

0016

0017

0018

0019

0070

0021

0022
SOBROUTINE PICTT

COHHON / PI NBL K / NFIN , NREGP

COHHON/DRAH/ARRAY X $(50,50)$, ARRAYY $(50,50)$

COHHON/THERM/RA, KB , NPT YP

DIMENSION XX $(500), Y Y(500)$

CALL CALCHE

CALL BGNPI $(-1)$

CALL PAGE $(14 . .11$.

CA LL TITLE (' PISH DISTRI B OTION\$ ' 100, ' LENGTH ', 6, DEPTH', 5, 10, 6.)

CALL GRAP $(0, ., \operatorname{SCALE'}, 100 \ldots, 0$, SCALE',65.)

$X$ MAX $=100$.

$X$ H IN $=0.0$

YHAX $=60$.

YMIN $=0.0$

$I=1$

DO $50 \mathrm{~J}=1$, NREGP

$X X(J)=A R R A Y X(I, J)$

$Y Y(J)=A R R A Y Y(I, J)$

50 CCONINOE

CA I.I. C.URVP, $(X X, Y Y, N R F, P, \cap)$

RETU RN

END 


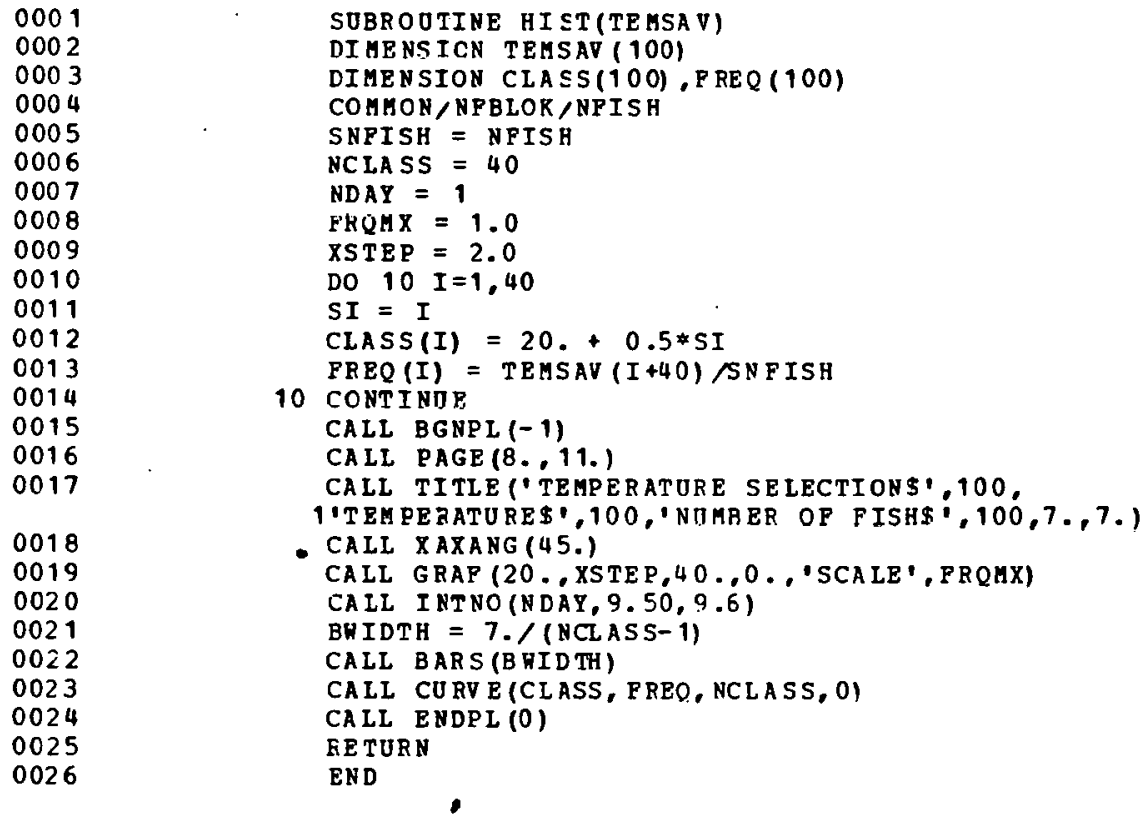


ORNL/TM-6310

INTERNAL DISTRIBUTION

$\begin{aligned} \text { 1. } & \text { S. M. Adams } \\ \text { 2-11. } & \text { S. I. Auerbach } \\ 12 . & \text { L. W. Barnthouse } \\ 13 . & \text { R. W. Brocksen } \\ 14 . & \text { R. L. Burgess } \\ 15 . & \text { D. S. Carroll } \\ \text { 16. } & \text { S. W. Chr istensen } \\ \text { 17-26. } & \text { C. C. Coutant } \\ 27 . & \text { D. K. Cox } \\ \text { 28-38. } & \text { D. L. DeAngel is } \\ 39 . & \text { J. W. Elwood } \\ \text { 40. } & \text { W. R. Emanue1 } \\ \text { 41. } & \text { R. H. Gardner } \\ 42 . & \text { W. F. Harr is } \\ 43 . & \text { K. D. Kumar } \\ 44 . & \text { J. B. Mankin } \\ 45 . & \text { J. S. Mattice } \\ 46 . & \text { R. B. McLean } \\ 47 . & \text { R. V. O'Nei11 }\end{aligned}$

48. H. Postma

49. D. E. Reichle

50. C. R. Richmond

51. B. Schaich

52. H. H. Shugart

53. R. H. Strand

54. E. G. Struxness

55. J. S. Suffern

56. R. I. Van Hook, Jr.

57. W. Van Winkle, Jr.

58. D. S. Vaughan

59. H. Waddle

60. J. A. Watts

61. Biology Library

62-63. Central Research Library

64-65. Laboratory Records Dept.

66: Labor atory Records, ORNL-RC

67. ORNL Y-12 Technical Library

68. ORNL Patent Office

\section{EXTERNAL DISTRIBUTION}

69. Richard 0 . Anderson, Cooperative Fishery Research Unit, University of Missouri, Columbia, MO 65201

70. C. A. Barans, South Carolina Marine Resources Research Institute, P. 0. Box 12559, Charleston, SC 29412

71. Roger A. Barnhart, Cooperative Fishery Research Unit, Humboldt State University, Arcata, CA 95521

72. T. L. Beitinger, Dept. of Fisheries and Wildlife, Texas A \& M University, College Station, TX 77840

73. D. H. Bennett, Virginia Polytechnic Institute and State University, Blacksburg, VA 24060

74. Theodore C. Bjornn, Cooperative Fishery Research Unit, University of Idaho, Moscow, ID 83843

75. Char les F. Bryan, Cooperative Fishery Research Unit, Louisiana State University, Baton Rouge, LA 70803

76. Robert L. Butler, Cooperative Fishery Research Unit, Pennsylvania State University, University Park, PA 16802

77. D. S. Cherry, Center for Environmental Studies, Virginia Polytechnic Institute and State University, Blacksburg, VA 24060

78. J. P. Clugston, Southeast Reservolr Investigations, Clemson University, Clemson, SC 29631

79. Daniel W. Coble, Cooperative Fishery Research Unit; University of Wisconsin, Stevens Point, WI 54481

80. A. E. Dizon, National Marine Fisheries Service, Honolulu, HI 96800 
81. L. Farges, IAEA, Karnter Ring 11, P. 0. Box 590 A-1011, Vienna, Austria

82. R. Don Estes, Cooperative Fishery Research Unit, Tennessee Technological University, Cookeville, TN 38501

83. F. E. J. Fry, University of Toronto, Toronto, Ontario, Canada

84. J. R. Gammon, Biology Department, DePauw University, Greencast le, IN 46135

85. J. W. Gibbons, Savannah River Ecological Laboratory, Aiken, SC 29801

86. J. Gift, Ichthyological Associates, Inc., New Jersey Marine Ecological Study, 3201 Bayshore Ave., Brigantine, NJ 08203

87. C. P. Goodyear, Power Plant Team, U. S. Department of the Interior, Ann Arbor, MI 48105

88. Richard W. Gregory, Cooperative Fishery Research Unit, Montana State University, Bozeman, Ml 59715

89. Bernard L. Griswold, Cooperative Fishery Research Unit, Ohio Statc University, Culumbus, $\mathrm{OH} 43210$

90. Donald C. Hales, Cooperative Fishery Research Unit, South Dakota State University, Brookings, SD 57006

91. Richard W. Hatch, Cooperative Fishery Research Unit, University of Maine at Orono, Orono, ME 04473

92. Melvin T. Huish, Cooperative Fishery Research Unit, North Carolina State University, Raleigh, NC 27606

93. P. R. Kamath, Bhabha Atomic Research Center, Trombay, Bombay, India

94. J. R. M. Kelso, Canada Centre for Inland Waters, Burlington, Ont ario, L7R 4A6, Canada

95. W. C. Leggett, Biology Department, McGill University, Montreal, Canada

96. John A. Maciolek, Conperative Fishery Research Unit, University of Hawaii, Honolulu, HI 96822

97. J. J. Magnuson, Laboratory of Limnology, Univ. of Wisconsin, Madison;, WI 53703

98. 0. Eugene Maughan, Cooperative Fishery Research Unit, Oklahoma State University, Stillwater, OK 74074

99. James A. McCann, Chief, Division of Fishery Researr, U, U. S. Department of the Interior, Fish and Wildlife Service, Washington, DC 20240

100. R. W. McCauley, Biology Department, Wilfred Laurier University, Water 100 , Ontarin, N?I 3C.5, Canada

101. Wrlliam J. McConne 11, Cooperative Fishery Research Unit, Colorado State University, Fort Collins, CO 80521

102. J. H. McCormick, USEPA, Environmental Research Laboratory, Duluth, MN 55800

103. J. McMaho, Atomic Energy of Canada, Ltd., Chalk River, Canada

104. J. W. Meldrin, I chthyological Associates, 100 S. Cass St:, Midd letown, DE 19709

105. D. Miller, USEPA, Environmental Research Laboratory, Narragansett, RI 02882

106. Robert J. Muncy, Cooperative Fishery Research Unit, Iowa State University, Ames, IA 50010 
107. W. Neill, Dept. of Fisheries and Wildlife, Texas A \& M University, College Station, TX 77840

108. John G. Nickum, Cooperative Fishery Research Unit, Cornell University, Ithaca, NY 14850

109. Gar land B. Pardue, Cooperative Fishery Research Unit, Virginia Polytechnic Institute and State University, Blacksburg, VA 24061

110. John S. Ramsey, Cooperative Fishery Research Unit, Auburn University, Auburn, AL 36830

111. Roger J. Reed, Cooperative Fishery Research Unit, University of Massachusetts, Amherst, MA 01002

112. Robert $E$. Re inert, Cooperative Fishery Research Unit, University of Georgia, Athens, GA 30601

113. J. M. Reutter, F. T. Stone Laboratory, Put-In-Bay, OH 43456

114. W. Reynolds, Biology Dept., Pennsylvania State University, Wilkesbarre, P.A 18708

115. F. P. Richards, Ecological Analysts, Melville, NY 11746

116. W. Schikarski, Nuclear Research Center, Karlsruhe, Federal Republic of Germany

117. M. Schneider, Ecosystems Dept., Battelle Northwest, Richland, WA 99352

118. Carl B. Schreck, Cooperative Fishery Research Unit, Oregon State University, Corvall is, OR 97331

119. S. A. Spigarel1i, Argonne National Laboratory, Argonne, IL 60439

120. J. R. Stauffer, Gunter Hall, Frostbury State College, Frostburg, MD 21532

121. Jerry C. Tash, Cooperative Fishery Research Unit, University of Arizona, Tucson, AZ 85721

122. M. Van deu Avyle, Cooperative Fisheries Unit, Tennessee Tech. University, Cookville, TN 38501

123. L. Wilson, Dept. of Forestry, Wildlife, and Fisheries, University of Tennessee, Knoxville, TN 37916

124. Richard R. Whitney, Cooperative Fishery Research Unit, University of Washington, Seattle, WA 98105

125. Richard S. Wydoski, Cooperative Fishery Reseapch Unit, Utah State University, Logan, UT 84321

126. Research and Technical Support Division, DOE-ORO.

127-153. Technical Information Center, Oak Ridge, TN 37830 